\title{
Climatic variability over the last 30,000 years recorded in La Piscina de Yuriria, a Central Mexican Crater lake (DOI: 10.1002/jqs.2846)
}

Jonathan A. Holmes ${ }^{1^{*}}$, Sarah E. Metcalfe ${ }^{2}$, Heather L. Jones ${ }^{3}$, Jim D. Marshall ${ }^{4}$.

${ }^{1}$ Environmental Change Research Centre, Department of Geography, University College London, Gower Street, London, WC1E 6BT, UK

${ }^{2}$ School of Geography, University of Nottingham, University Park, Nottingham, NG7 2RD, UK

${ }^{3} 15$ Poppy Close, Southwater, Horsham, RH13 9GW, UK

${ }^{4}$ Department of Earth, Ocean and Ecological Sciences, University of Liverpool, Liverpool, L69 3GP, UK

Corresponding author: Jonathan A. Holmes, j.holmes@ucl.ac.uk

Running head: Palaeolimnology of a Mexican Crater Lake

ABSTRACT: The Trans-Mexican Volcanic Belt provides an excellent setting for reconstruction of late Quaternary climate from different natural archives. Moreover human impact on the landscape since the mid Holocene provides a good opportunity to investigate the complex interplay of natural and anthropogenic forcing of landscape change. However despite the wealth of records, understanding of the environmental history of the region and its wider significance for climate change across the northern neotropics remains incomplete. We present a radiocarbon-dated, multiple-proxy (sedimentology, sedimentary geochemistry, ostracods, diatoms, stable isotopes) record of climatic and environmental change based on the lacustrine sediments from La Piscina de Yuriria, a hydrologically-closed volcanic crater in the northern TMVB. Much of the last glacial interval was characterised by low effective moisture associated with a weakened North American Monsoon (NAM) although the interval from 30,000 to 27,500 aBP experienced abrupt changes in rainfall. The period corresponding to the late glacial stadial was also dry and the lake may have dried out at this time. There was a change to wetter but variable conditions during the early Holocene as the NAM strengthened. Progressive drying during the later Holocene was accompanied by phases of catchment disturbance, which were partly the result of human impact.

KEYWORDS: Trans-Mexican Volcanic Belt; Palaeolimnology; diatoms; ostracods; stable isotopes 
50 The highlands of the Trans-Mexican Volcanic Belt (TMVB), which cross Mexico at around

$5119^{\circ} \mathrm{N}$, provide a range of opportunities for reconstructing past climates through the study of

52 the sediments in its many lake basins, the availability of glacial deposits, tree ring records

53 and a wealth of historical documents (primarily since the Spanish conquest in 1521). In

54 spite of these many possibilities, understanding of climatic variability over the late

55 Quaternary, particularly the late Pleistocene and early Holocene, is still rather limited

56 (Caballero et al., 2010). A number of factors help to explain this, including poor dating control of many records, the effects of tectonic and volcanic activity, and especially human disturbance, which over at least the last 4000 years has had a profound impact on the natural environment to the extent that only records from the highest elevations may be unaffected (e.g. Lozano-Garcia and Vazquez-Selem, 2005). Lake sediment records have

61 dominated studies of central Mexican palaeoclimatology, although recent speleothem records (Bernal et al., 2011) have also made a contribution. Palynology has played a central role in palaeolimnological investigations dating back to the 1950s (Sears and Clisby, 1995; Watts and Bradbury, 1982; Goman and Byrne, 1998; Lozano-Garcia et al.,

66 TMVB has presented further challenges given the limited taxonomic resolution of these pollen types in standard palynology and the impact of long-range dispersal, especially of pine pollen (Correa-Metrio et al., 2012). The climatic interpretation of pollen diagrams from the TMVB has often hinged on decisions about the climatic conditions that changing proportions of pine and oak represent, or indeed whether the presence of large

71 percentages of pine means that pine trees were actually present (c.f. Brown, 1985; Park et al., 2010). Pollen records are also highly susceptible to anthropogenic disturbance, although the distinctive presence of Zea mays pollen in records is a clear indicator of agricultural activity close to lakes. To help to resolve some of the uncertainties around 
pollen-based reconstructions, the application of palaeolimnological methods, particularly diatom, geochemical, isotopic and mineralogical analyses, has become increasingly common across the TMVB. Whilst not immune to many of the complicating factors outlined above, this multi-proxy approach has helped to improve our understanding of both climatic and environmental change in this area. In this paper we present a well-dated palaeolimnological record from a crater lake, La Piscina de Yuriria, on the southern edge of the Valle de Santiago region, southern Guanajuato, which extends back some 30,000 years (all ages quoted in this paper that relate to the radiocarbon time-span are in calendar years unless otherwise stated). This is considered in the context of other data from adjacent crater lakes in the Valle de Santiago area and other lakes in the wider region to explore the timing and nature of climatic change and human impact.

The present-day climate of the region, and climate forcing mechanisms over the late Quaternary, are complex. Central Mexico falls under the influence of the North American Monsoon (NAM). Variations in rainfall are forced by northern hemisphere summer insolation over the longer term (millennial timescales) linked to precession, which has caused changes in the position of the inter-tropical convergence zone (ITCZ) (Metcalfe et al., 2015). On shorter (centennial and shorter timescales), changes in the Pacific and Atlantic Oceans, both of which are important moisture sources, have influenced rainfall over tropical North America and Central America. During the last glacial and first half of the Holocene, the presence of the Laurentide Ice Sheet influenced the climate of the NAM region. The ice sheet had direct effects, through its impact on the position of the jet stream and the mid-latitude westerly winds, and indirectly via meltwater influx into the Gulf of Mexico, a significant moisture source (Aharon, 2003). As the influence of orbitally-forced summer insolation waned over the course of the Holocene, the effect of other factors such as sea-surface temperature variations in the Pacific and Atlantic, linked to various inter- 
101 annual modes of ocean-atmosphere re-organisation, has become increasingly important

102 (Metcalfe et al., 2015).

104 Study Region

105 La Piscina de Yuriria lies within the Valle de Santiago, which is located at the northern 106 edge of the Michoacán-Guanajuato Volcanic field (Fig. 1), and is distinctive because of the 107 presence of at least seventeen maar type volcanoes, of which a number contained lakes 108 (Aranda Gomez et al., 2013). It lies on the margin of the volcanic uplands to the south and 109 the lowlands of the Rio Lerma, in an area known as the Bajío, which became a very 110 important agricultural region during the Spanish Colonial period (Butzer and Butzer, 1993).

112 Seven maar lakes have been identified around the town of Valle de Santiago, of which 113 four contained water in 1900 (Ordonez, 1900). K-Ar dating of some of the maars puts their 114 formation to between 1.2 Ma (Hoya San Nicolas) and 0.07 Ma (Hoya La Alberca).

115 Unfortunately, the maar that contains La Piscina de Yuriria was not dated, although the 116 adjacent shield volcano is believed to date to 6.9 Ma (Aranda-Gomez et al., 2013). It has 117 been suggested that these maar lakes were once set within a large palaeolake, which 118 extended from the modern Laguna de Yuriria, northwards around the modern town of 119 Valle de Santiago. The maars have very small catchment areas and the lakes within them 120 were supported by the waters of the underlying Salamanca aquifer. Unfortunately, this 121 aquifer has been heavily exploited (there are more than 1600 active wells), which has 122 resulted in a drawdown of about $2 \mathrm{~m} \mathrm{yr}^{-1}$ over the past 25 years (Alcocer et al., 2000). As 123 a result all the maars are now dry, even those that contained deep lakes in the early 124 1980s. Alcocer et al. (2000) report on the many undesirable consequences of this 125 desiccation, including the loss of endemic fish species and lake margin wetland habitats, 126 the economic effect of the loss of fisheries and alkali fly collection and adverse health 
127 effects due to the mobilisation of alkaline dust. La Piscina de Yuriria contained a lake 128 approximately $2 \mathrm{~m}$ deep in 1981 and was then observed to dry out through the 1980s, with 129 the development of a salt crust across the basin floor. Freshwater springs around the 130 margins of the lake within the crater also dried up. A shallow lake was re-established in 131 the early 1990s, which was then made permanent in the early 2000 s by the pumping of 132 groundwater back into the crater. As this was one of the basins where adverse health 133 effects were reported due to dust mobilisation, this re-wetting of the basin may have been 134 a response.

136 The Valle de Santiago area lies towards the northern margin of what was the 137 MesoAmerican cultural area in the pre-Hispanic period. There is limited evidence for 138 settlements during the Preclassic period associated with the Chupicuaro culture (ca. 800 1390 BC). Population expanded during the Classic period (ca. AD $300-900$ ) when urban 140 centres developed across the Bajío. In the late Postclassic (after ca. AD 1300) the area 141 lay near the frontier between the settled Purépecha (Tarascans) to the south and the 142 nomadic Chichimec to the north (Gorenstein and Pollard, 1983). A church (convento) was 143 built at Yuririapundaro (the Purépecha name for Yuriria) in 1550. The translation of 144 Yuririapundaro is 'Lake of Blood', referring to the distinct red colour of the water in the 145 crater (de Escobar 1729 in Gomez de Orozco, 1972). A similar red colour, probably the 146 result of blooms of sulphur bacteria, was observed at the lake in the 1980s. According to 147 Park et al. (2010) the Spanish settled in Valle de Santiago in the early $17^{\text {th }}$ century 148 initiating a period of intensive agricultural exploitation that has lasted until the present day.

150 The dramatic effects of water extraction on the maar lakes attracted work on what had 151 been the deep lakes of Hoya la Alberca and the Hoya Rincon de Parangueo (Kienel et al., 152 2009; Park et al., 2010) partly in an effort to retrieve cores of laminated sediments before 
153 these became lost through deflation or profoundly disturbed by desiccation and secondary

154 precipitation of evaporite minerals. The Hoya Rincon de Parangueo record goes back to 1559600 aBP. Prior to this, there had been work on the Hoya San Nicolas (Brown, 1985;

156 Metcalfe et al., 1989), which had been cored in 1979 shortly after it dried out. The basal 157 date on this core was 12,600-12,700 aBP. This maar was re-cored in 2001 with the results 158 reported by Park et al. (2010) giving a record believed to extend back to 11,600 aBP (but 159 not directly dated). As described further below, La Piscina de Yuriria was cored in 1981 160 and 1982 prior to its desiccation.

162 The interpretation of sequences from the Valle de Santiago maar lakes has been subject 163 to the common uncertainties that affect records from the TMVB region. The interpretation 164 of pine pollen (or the ratio of pine to pine + oak) has been particularly significant here, with 165 Park et al. (2010) rejecting Brown's earlier interpretation of wetter conditions between ca. $1665700 \mathrm{aBP}$ and $3800 \mathrm{aBP}$ in the Hoya San Nicolas. The shallower lakes also seem to have 167 dried up quite regularly through the Holocene, possibly three times in the case of Hoya 168 San Nicolas (Park et al., 2010). The basic framework of change based on these earlier 169 studies seems to be as follows: a cool and relatively moist late glacial (prior to $\sim 12,700$ $170 \mathrm{aBP}$ ); a variable late glacial to Holocene transition; a dry (possibly very dry) early 171 Holocene; the rapid establishment of wetter conditions around 8400 aBP lasting until 5700 172 aBP; dry $5700-3800$ aBP, then wetter again, but not as wet as the period between 173 around 8400 and $6000 \mathrm{aBP}$. The late Holocene has been profoundly influenced by human 174 activity with evidence of maize cultivation and enhanced erosion (especially 2200 to 1300 175 aBP). Both Metcalfe et al. (1989) and Park et al. (2010) report a cessation of human 176 disturbance around 1000 aBP followed by renewed activity after 400 aBP probably 177 associated with Spanish settlement. Our new data from La Piscina de Yuriria allow us 
178 both to extend this record back into the last glacial and to test the framework outlined 179 above.

\section{Study site}

182 This study is based on lake sediment records from La Piscina de Yuriria $\left(20^{\circ} 30^{\prime} \mathrm{N}\right.$;

$183101^{\circ} 08^{\prime} \mathrm{W}, 1740 \mathrm{~m}$ a.s.I), which is one of the small (area $=0.75 \mathrm{~km}^{2}$ ), hydrologically-closed 184 maar lakes in the Valle de Santiago region (Fig. 1). The basaltic basin experiences a 185 subhumid, subtropical climate with annual precipitation of $700-800 \mathrm{~mm}$ and supports 186 subtropical thorn bush scrub around the lake and sparse oak woodland above $2200 \mathrm{~m}$ 187 a.s.I. (Metcalfe and Hales, 1994; Metcalfe et al., 1994). The lake seems to have been 188 generally shallow in recent times (e.g. $2 \mathrm{~m}$ deep in 1981 and 1982, <1 $\mathrm{m}$ in 1992, >1.8 $189 \mathrm{~m}$ in 2004) and has dried up totally in some years (e.g.1989). The lake was saline as a 190 result of evaporative enrichment, as well as highly eutrophic, with an alkalinity/Ca ratio >>1 191 and $\mathrm{Na}-\mathrm{CO}_{3}-\mathrm{Cl}$-type composition indicating that evaporative evolution occurred along 192 pathway IIIA of Eugster and Hardie (1978). The lake was fed by several circum-neutral to 193 alkaline springs that were fresh to slightly brackish (Table S1) and also of $\mathrm{Na}-\mathrm{HCO}_{3}$ type. 194 Evaporative enrichment is also reflected in the limited stable isotope data for the input 195 water (-9.2\%) versus lake water (+0.7\%o) (Table S1). Recent water-level changes have 196 been the result of groundwater extraction for irrigation (e.g. Metcalfe and Hales, 1994) and 197 later artificial recharge; variations during the late Quaternary, which form a major focus of 198 the present study, have largely been driven by changes in effective moisture (precipitation 199 minus evaporation, or P-E), as discussed below.

\section{Materials and methods}


203 Two lake sediment cores, namely cores YC1 (length $4 \mathrm{~m}$ ) and YC2 (14.3 m), were

204 recovered from La Piscina de Yuriria from under $2 \mathrm{~m}$ of water in 1981 and 1982,

205 respectively, by members of the Tropical Palaeoenvironments Research Group, at the

206 time based at the University of Oxford, UK. Cores were initially wrapped in clingfilm and

207 aluminium foil and stored in plastic tubes at $4^{\circ} \mathrm{C}$ prior to sectioning into $1 \mathrm{~cm}$ slices,

208 typically at $5 \mathrm{~cm}$ intervals, for analysis. Some of the data for core YC1 have been

209 published previously (Metcalfe and Hales, 1994; Metcalfe et al., 1994) but are summarised

210 here alongside previously unreported data for that core and for YC2.

Physical sedimentology

213 Sediment samples from YC1 and YC2 were analysed for organic carbon content using

214 loss on ignition at $450{ }^{\circ} \mathrm{C}$, and for carbonate content by calcimetry. Low-frequency

215 magnetic susceptibility was measured using a Bartington MS1 magnetic susceptibility

216 meter.

218 Bulk sediment geochemistry

219 Dried sediment samples from $\mathrm{YC} 1$ were digested using a combination of $\mathrm{HNO}_{3}, \mathrm{HF}$ and

$220 \quad \mathrm{H}_{2} \mathrm{O}_{2}$ following Dean and Gorham (1976). The resulting residue was taken up in dilute $\mathrm{HCl}$

221 prior to analysis of major and minor metals using atomic absorption spectrophotometry

222 (AAS). Samples from YC2 were prepared using the sequential digestion method of

223 Engstrom and Wright (1984) and each separate fraction analyses for major and minor

224 metals as for YC1. However, initial inspection of the results indicated that the fractionation

225 had not worked well for these complex sediments. Consequently, the results for the

226 separated fractions were summed and the data treated as 'bulk' analyses, as for YC1.

227 Only selected metals are reported here, namely Fe, Mn, Al, and K, all of which are 
228 abundant in catchment soils and sediments, and so are regarded as good tracers of 229 inwash, as discussed in further detail below.

231 Stable isotopes in endogenic carbonate

232 Bulk, dried sediment samples from YC1 were sieved through an 80 $\mu m$ mesh to remove 233 shell material, treated with Clorox to remove organic carbon and then dissolved in $100 \%$ 234 phosphoric acid. The evolved $\mathrm{CO}_{2}$ was then analysed for oxygen and carbon isotopes 235 using a VG 'Micromass' mass spectrometer at the Laboratoire d'Hydrologie et de 236 Géochimie Isotopique, Université de Paris-Sud. Samples from YC2 were prepared in a 237 similar way and analysed using a modified SIRA mass spectrometer at the University of 238 Liverpool. All stable isotope results are reported in standard delta notation relative to the 239 PDB standard.

241 As part of the evaluation of the stable isotope results, the mineralogy of the carbonate 242 fractions was assessed by X-ray diffraction using Phillips PW1320/10 and PW1050 X-ray 243 diffractometers. Specifically, the Mg content of calcite was assessed using the method of 244 Goldsmith et al. (1961)

Ostracods

247 Bulk sediment samples were disaggregated in $\sim 5 \% \mathrm{H}_{2} \mathrm{O}_{2}$, sieved through a $63 \mu \mathrm{m}$ sieve 248 and the coarse fractions used for extraction of ostracod shells under a low-power binocular 249 microscope. Because ostracod abundance varied dramatically, in some samples all of the 250 ostracod valves were picked whereas in richer samples, only the first 350 valves were 251 picked and overall abundance then estimated based on the weight of sediment examined. 252 However, the unpicked fraction of rich samples was inspected for the presence of rare 253 species not identified in the original count. Despite poor ostracod shell preservation in 
many parts of the core, sufficiently well-preserved valves were found at a number of levels to permit stable-isotope analyses, which were used to complement analyses on the endogenic carbonate.

Specimens of ostracods from the picked fraction of YC2 were selected and studied carefully for signs of damage, dissolution or replacement. Suitable individuals were then cleaned carefully using a 000 size clean nylon paintbrush and ultra pure deionised water under a binocular microscope to remove surface contaminants. Stable-isotope analyses of multiple shells of Limnocythere sappaensis were analysed for oxygen and carbon isotopes using a VG Isocarb coupled to a VG Optima mass spectrometer at the NERC Isotope Geosciences Laboratory, Keyworth (UK). Two samples, composed of up to 8 individual valves, were analyzed at most core levels selected and a weighted mean value for $\delta^{18} \mathrm{O}$ and $\delta^{13} \mathrm{C}$ calculated for plotting purposes.

\section{Diatoms}

Diatom samples were prepared for analysis at $10 \mathrm{~cm}$ intervals in YC1 and $10-20 \mathrm{~cm}$ intervals (depending on sample availability) in $\mathrm{YC}$. In $\mathrm{YC}$, only material from $4 \mathrm{~m}$ to the base was sampled in detail after preliminary analysis (samples prepared every $25-30$ $\mathrm{cm}$ ) had shown that the upper $4 \mathrm{~m}$ of the sequence seemed to match well with YC1. Poor valve preservation between $7 \mathrm{~m}$ and $12 \mathrm{~m}$ meant that the majority of samples were taken below and above this interval. Core samples were complemented by a surface sediment sample and water samples from the lake margin. Samples were treated to remove carbonates and organic matter following the method of Battarbee (1986). In some cases strong acids $\left(\mathrm{H}_{2} \mathrm{SO}_{4}\right.$ or $\left.\mathrm{HNO}_{3}\right)$ were used to break up clumps of sediment. The final suspension was mounted onto coverslips using Naphrax. The same method was used to prepare surface sediment samples. Where possible, 400 valves were counted from each 
280 level, although at levels with poor preservation this was sometimes reduced to $100-200$

281 valves. Identifications were carried out using standard floras including Gasse (1986),

282 Krammer and Lange Bertalot (1988, 1991a and b), Patrick and Reimer (1966, 1975),

283 Schoeman and Archibald (1977). The separation of Navicula (Craticula) elkab from

284 Craticula halophila proved to be an important part of the study and is discussed in

285 Metcalfe (1990). The results from YC1 were published in Metcalfe and Hales (1994), and

286 preliminary results from YC2 were described in Park (1999). Diatom results are presented 287 here as percentages of the full counts. Species present at less than $2 \%$ and only 288 occurring in one sample are not plotted here.

290 Initial zonation was carried out using CONISS, the stratigraphically constrained cluster291 analysis program within Tilia (Grimm, 1987). The counts from the core samples were also analysed using CANOCO and TWINSPAN. TWINSPAN (Hill, 1979; Jongman et al., 1992) provided a clustering that was not constrained stratigraphically. CANOCO (ter Braak, 1988) was used to explore further the variation between samples and species. The latter analyses were used to determine whether the lake diatom assemblages showed repeat occurrences through time and to explore that trajectory of change.

Chronology

Independent chronologies were established using AMS or radiometric radiocarbon dating 300 on bulk organic carbon or carbonate (8 levels were dated from YC1 and 16 from YC2).

301 Lack of appropriate material precluded the dating of terrestrial plant macrofossils from 302 either core, but the absence of carbonate bedrock within the catchment means that 303 hardwater error is unlikely to affect radiocarbon dates at this site. Radiocarbon 304 measurements were performed at the Oxford University Radiocarbon Accelerator Unit, 305 Simon Fraser University Radiocarbon facility, Laboratoire d'Hydrologie et de Géochimie 
306 Isotopique, Université de Paris-Sud, the NERC Radiocarbon Facility, East Kilbride and the

307 Arizona AMS Laboratory, University of Arizona. Dates were calibrated using IntCal13

308 (Reimer et al., 2013). For each core, outliers were identified and excluded from

309 subsequent age modeling, which was undertaken using Clam 2.2 (Blaauw, 2010).

310 Although some of the radiocarbon dates have been published previously, we report them

311 again here for the sake of completeness and because we have revised the calibrations.

313 Results

314 Chronology

315 The age model for $\mathrm{YC} 1$ is based on 7 of the 8 radiocarbon dates for that core (Table 1,

316 Fig. 2) and the age-depth pairs well described by a $3^{\text {rd }}$-order polynomial curve. The age 317 model for YC2 is based on 12 of the 16 radiocarbon dates (Table 1, Fig. 2) and the age318 depth pairs well described by a $3^{\text {rd }}$-order polynomial curve. The age models were used to 319 assign ages to each depth within the respective cores. An assessment of the comparability 320 of the independent age models for YC1 and YC2 was also undertaken by comparing 321 variations in their physical sedimentology, which would be expected to change 322 synchronously in the two cores: this assessment is discussed below.

Physical sedimentology

325 Cores YC1 and YC2 core are both composed predominantly of brown to grey, 326 diatomaceous gyttja. In the lower sections of YC2 (at $26,300,19,900$ and 8300 aBP), 327 centimetre-scale sand layers are present. Desiccation surfaces, represented by sub328 vertical fractures infilled with darker material, occur at several depths in the interval 329 between 16,800 and 14,300 and near the top of the sequence ( 800 aBP). Nodular, 330 siliceous concretions were observed between the base of the sequence and $\sim 17,500$ aBP. 331 The interval $100-50 \mathrm{~cm}$ (representing $\sim 1100-500$ aBP) was not recovered in YC2. 
333 Organic carbon content, estimated from loss-on-ignition (LOI) at $450^{\circ} \mathrm{C}$, varies between $\sim 9$ 334 and $44 \%$ (Fig. 3). From the beginning of the YC2 record until $\sim 14,000$ aBP, values

335 average $\sim 15 \%$, increasing and becoming more variable after this time, with peaks up to 44 $336 \%$. The LOI record in the upper part of YC2 is well replicated in YC1. Carbonate content 337 averages around $18 \%$ from the beginning of the record until 14,200 aBP, but with peaks 338 up to $40 \%$ in places. Between 14,000 and 7800 aBP, carbonate content falls to $14 \%$ and 339 becomes less variable. From 7800 aBP to the end of the YC2 record, there is a sharp 340 increase to an average of $33 \%$, with transient peaks up to $45 \%$. The pattern of change in 341 YC1 replicates that in the upper part of YC2, but values are systematically lower.

Magnetic susceptibility $(\chi)$ values (Fig. 3) are typically lower than $10 \times 10^{-7} \mathrm{~m}^{3} \mathrm{~kg}^{-1}$ but with a number of sharp peaks at several levels and a more gradual increase and then decline between $\sim 10,100$ and 6900 aBP. Values rise sharply at 3600 aBP, after which they remain high and show increased variability. The pattern of change in YC1 replicates that in the upper part of YC2.

Geochemistry and stable isotopes

350 Concentrations of $\mathrm{K}, \mathrm{Fe}, \mathrm{Mn}$ and $\mathrm{Al}$ are variable throughout the cores. For much of the 351 lower part of YC2 values are generally low, although there are some transient peaks.

352 Values typically become higher and more variable after about 5100 aBP in YC2, a pattern 353 that is generally replicated in YC1. There is strong and statistically-significant correlation 354 amongst all of the metals discussed here in YC1 and in the section of YC2 covering the 355 past $\sim 5000$ years. Correlations are weaker for the earlier part of YC2 (Table S2). 
Stable isotope values are available for fine-grained carbonates and, for a few levels from YC2 only, for ostracod shells (Fig. 4). Mineralogical determinations showed that the calcite present within the core had low magnesium content ( $\leq 4$ mole $\%)$ : nevertheless, appropriate corrections were made to the $\delta^{18} \mathrm{O}$ values following Tarutani et al. (1969). From the beginning of $\mathrm{YC} 2$ to $26,600 \mathrm{aBP}, \delta^{18} \mathrm{O}$ and $\delta^{13} \mathrm{C}$ values are typically low but variable (from about $0 \%$ to around $-11 \%$ and +7.6 to $-1 \%$, for $\delta^{18} \mathrm{O}$ and $\delta^{13} \mathrm{C}$, respectively) and strongly covariant (Fig. 5). Between 25,000 and 14,200 aBP, the stableisotope values are at relatively low resolution, and typically values are higher than in the preceding interval (up to about $+3 \%$ and $+8 \%$ for $\delta^{18} \mathrm{O}$ and $\delta^{13} \mathrm{C}$, respectively) and covariant. Between 10,900 and 6600 aBP, there is a further rise in variability, but $\delta^{18} \mathrm{O}$ and $\delta^{13} \mathrm{C}$ covary as before. Between 6600 and 4500 aBP, there is a significant shift in the pattern of stable isotope variability, with $\delta^{18} \mathrm{O}$ values remaining relatively constant, but $\delta^{13} \mathrm{C}$ increasing up to $+15.4 \%$. After $4500 \mathrm{aBP}, \delta^{18} \mathrm{O}$ values vary between about 0 and $-2.7 \%$ o and $\delta^{13} \mathrm{C}$ values are markedly reduced compared with the preceding interval. The overlapping sections of YC1 and YC2 show similar patterns of change, especially for $\delta^{13} \mathrm{C}$. The low-resolution ostracod values are typically ${ }^{18} \mathrm{O}$-enriched and ${ }^{13} \mathrm{C}$-depleted compared with those for fine-grained carbonates.

\section{Ostracods}

Ostracod abundance varies dramatically, between zero (i.e. barren levels) and 35,000 valves per gram of sediment (Fig. 4). Significant zones of very high abundance are present from the beginning of the YC2 record to until 28,700 aBP and at $21,900-21,300$ aBP, $17,800-15,900$ aBP, 13,700 - 12,900 aBP, $4800-2700$ aBP, $2000-1100$ aBP. Significant zones that are barren or contain very few ostracods occur at $28,500-27,800$ aBP, $19,000-18,500$ aBP, 15,400 - 14,400 aBP, 10,500 - 8300 aBP, 5300- 4900 aBP. The zones of high abundance generally contain monospecific assemblages of 
Limnocythere sappaensis (both males and females): zones of lower abundance typically support other species as well, including at least one species of candonid, Heterocypris sp., Physocypria sp., Potamocypris sp., Strandesia sp. and Cypria sp. Although L. sappanesis is regarded as conspecific with Limnocythere inopinata (e.g. Martens, 1994), we adopt the name $L$. sappaensis here since this is widely used for the species in North America.

\section{Diatoms}

The diatom assemblages from surface sediment samples collected in $2 \mathrm{~m}$ of water in 1982 were dominated by Navicula (Craticula) elkab (22\%), N. (C.) halophila (13\%) and a variety of Nitzschia species. A sample taken in 1997 in $0.3 \mathrm{~m}$ of water, just as a lake was becoming re-established, was dominated by Anomoeneis sphaerophora (48\%) and Navicula (Cracticula) elkab (16\%). Anomoeoneis costata and Chaetoceros mulleri spores made up $8 \%$ of the count each (Davies, 2000). A sample taken in 2004 , at the edge of the lake, was dominated by Navicula (Craticula) halophila (56\%), a range of Nitzschia species, Chaetocerous muelleri (some as resting spores) and Anomoeoneis sphaerophora f. costata (Hill, 2006), although these each formed less than $6 \%$ of the assemblage. In 2004 , the lake was hypereutrophic, with TP $=584 \mu \mathrm{g} \mathrm{I}^{-1}$ and chlorophyll-a $127 \mu \mathrm{g} \mathrm{I}^{-1}$ (Hill, 2006).

Preliminary diatom analysis of samples from the top $4 \mathrm{~m}$ (past $\sim 5000$ years) of the YC2 core indicated the presence of similar assemblages to those reported in Metcalfe and Hales (1994), so efforts on this core were focused on the section below $4 \mathrm{~m}$. Here, results are presented from both core sequences (Fig. 6). As with the ostracods, diatom preservation is highly variable through the sequences. In YC2 there was little or no valve preservation between $22,100-10,400$ aBP $\mathrm{cm}$. In YC1 there are gaps in the record due to poor preservation between $2000-1100$ aBP. Both sequences are dominated by $N$. (C) halophila and N. (C) elkab, A. costata and A. sphaerophora, C. muelleri and a range of 
Nitzschia species. These assemblages are all similar to those found in surface sediment samples taken from the lake at different times, reflecting high (if varying) $\mathrm{pH}$ and alkalinity, and highly evaporated conditions. A more distinctive aspect of the core records is the abundance, at times, of small Navicula species (e.g. N. fluens, N. minusculoides, N. muralis).

\section{Discussion}

We discuss the chronology for the lake-sediment sequences and then the interpretation of each of the palaeolimnological variables, before proceeding to reconstruct the palaeolimnological history of La Piscina de Yuria for the late Quaternary.

Core YC1 covers the interval from about 4600 aBP to the coring date. The anomalous age at 44-46 cm probably represents inwash of older carbon from the catchment, substantiated by the magnetic susceptibility data. Core YC2 covers the interval from about 31,000 aBP to the coring date. The four dates that are omitted from the age model are all younger than expected, possibly the result of root penetration during times of low lake level. The general pattern of age-depth relationships for YC1 and the upper part of YC2 suggests good agreement between the two cores. Detailed comparisons based on the loss on ignition and magnetic susceptibility profiles (Fig. 2), which would be expected to agree for the two closely-located sequences, suggest a small ( 200 years) age offset, with YC2 being consistently older. The fact that small differences exist is perhaps not surprising given that different equivalent depths and contrasting materials were dated in the two cores (Table 1). However, rather than correct either one of the cores we prefer to use the age models defined for each respective core and then refer to the resulting uncertainties as appropriate. 
435 Loss on ignition (LOI) provides a good proxy for the organic carbon content of the 436 sediments (Dean, 1974). The carbon/nitrogen $(\mathrm{C} / \mathrm{N})$ ratios (available for YC1 only: data not 437 shown, but values vary between 11.6 and 49.4) indicate that the organic matter is of mixed 438 aquatic and terrestrial sources, suggesting that LOI provides a record of aquatic 439 productivity and terrestrial inwash at least for the past 4,600 years. The $\mathrm{CaCO}_{3}$ content of 440 the sediment is best explained by endogenic carbonate formation within the lake, since the 441 catchment is devoid of carbonate rocks or sediments. In such settings, calcium carbonate 442 precipitates from the water column when the lake becomes saturated with respect to 443 carbon minerals as a result of evaporative enrichment of water or mediated by aquatic 444 plants. However, enhanced aquatic productivity can also lead to carbonate dissolution 445 (e.g. Cohen, 2003) and carbonate formation also depends on supply of ions from the 446 catchment, meaning that the interpretation of sedimentary $\mathrm{CaCO}_{3}$ records is not always 447 straightforward.

The magnetic susceptibility of the sediments is strongly linked to inwash because the 450 volcanic soils are rich in magnetic minerals. Increases in $\chi$ in YC1 have therefore been 451 interpreted as inwash events associated with either natural or anthropogenic catchment 452 disturbance (Metcalfe and Hales, 1994). The elements $\mathrm{Fe}, \mathrm{Mn}, \mathrm{Al}$ and $\mathrm{K}$ are all associated 453 with weathered volcanic soils, and their concentrations in the lake sediments are 454 controlled by catchment inwash: Fe and Mn may also have been mediated by redox 455 conditions within the lake although we do not have direct evidence for this.

457 The oxygen and carbon isotope composition of lacustrine carbonate is a function of the 458 temperature and isotopic composition of the water in the case of oxygen, and the carbon459 isotope composition of dissolved inorganic carbon (DIC) for carbon. In subtropical dryland 460 lakes, such as La Piscina de Yuriria, the oxygen-isotope ratio of lake water is usually the 
461 dominant control on the oxygen-isotope composition of carbonate, and this varies with the 462 degree of evaporative enrichment (Talbot, 1990). The carbon-isotope composition of DIC 463 is a complex function of carbon source (catchment- vs lake-derived) and in-lake 464 modification as a result of fractionation during DIC uptake by aquatic plants for 465 photosynthesis, and exchange with atmospheric $\mathrm{CO}_{2}$ (Talbot, 1990) The same general 466 controls determine the isotopic values of biogenic carbonates, such as ostracod shells, but 467 there may be taxon-specific differences in the exact location and timing (especially 468 season) of carbonate formation compared with endogenic carbonate (e.g. Decrouy et al., 469 2011). Moreover, biogenic carbonate may not be precipitated in isotopic equilibrium with 470 lake water or DIC: ostracod shells, for example, demonstrate offsets from oxygen-isotope 471 equilibrium and are typically ${ }^{18} \mathrm{O}$-enriched compared with endogenic carbonate 472 precipitated in equilibrium with lake water (von Grafenstein et al., 1999). Further 473 palaeolimnological inferences can be drawn for the strength of covariance amongst 474 carbonate oxygen and carbon isotope values in sediment sequences, strong covariance 475 typically being associated with hydrologically-closed systems (Talbot, 1990).

Although the occurrence and abundance of different lacustrine ostracod taxa are 478 determined by a range of factors, in La Piscina de Yuriria, salinity, hydrochemistry and the extent to which the lake is seasonally permanent are likely to be the dominant controls. In saline lakes, there is moreover often a relationship between species diversity and ostracod 481 abundance: highly saline lakes are typically dominated by a single species that is present 482 in very high abundance (De Deckker and Forester, 1988).

484 Habitat, $\mathrm{pH}$, conductivity, ionic composition and nutrient levels are all major controls on the 485 presence and abundance of diatom species, with some species having well established 486 preferences in relation to some, or all, of these factors (e.g. Gasse, 1986; Kilham et al., 
1986). In La Piscina de Yuriria, the dominant controls over the full record appear to be those associated with changes in evaporative concentration ( $\mathrm{pH}, \mathrm{EC}$, ionic composition). $\mathrm{NaCl}$ and $\mathrm{Na}_{2} \mathrm{CO}_{3}$ waters have been shown to be particularly aggressive in relation to diatom dissolution (Barker et al., 1994), so it is likely that some species may be overrepresented in the sediment record due to their robust form and heavy silicification. This seems particularly likely in the case of the cysts of C. muelleri and may also apply to the more robust forms of species such as $A$. costata, Denticula elegans and Rhopalodia gibberula. Although the impact of differential preservation needs to be borne in mind when interpreting the fossil record, saline-lake diatoms are well established as indirect tracers of climate change (Gasse et al., 1997).

From the base of YC2, which dates to a little before 30,000 aBP, until around 27,500 aBP, the $\delta^{18} \mathrm{O}_{\text {carb }}$ record shows marked variability, with the lowest values equivalent to the minimum for the sequence as a whole, and the highest values close to the maximum (Fig. 4). There is strong covariance between $\delta^{18} \mathrm{O}_{\text {carb }}$ and $\delta^{13} \mathrm{C}_{\text {carb }}$ (Fig. 5) consistent with a hydrologically-closed lake undergoing temporal variations in the degree of evaporative enrichment (Talbot, 1990) in response to changes in effective moisture. The most negative $\delta^{18} \mathrm{O}_{\text {carb }}$ values equate to un-evolved lake water that was probably fed by springs and rainfall with lower $\delta^{18} \mathrm{O}$ than at present $\left(\delta^{18} \mathrm{O}\right.$ around $-9 \%$ in summer 1992: Table S1), possibly coupled with cooler conditions. In contrast, the most positive $\delta^{18} \mathrm{O}_{\text {carb }}$ values in this interval are best explained by evaporative enrichment under reduced effective moisture. The lowest $\delta^{13} \mathrm{C}_{\text {carb }}$ can be explained by equilibration with atmospheric $\mathrm{CO}_{2}$ whereas the more positive values require other, or additional, mechanisms to explain them. The uptake of ${ }^{12} \mathrm{C}$ during aquatic photosynthesis by aquatic macrophytes or algae can lead to an increase in the $\delta^{13} \mathrm{C}_{\mathrm{DIC}}$ and hence of endogenic carbonates, but such an explanation appears inconsistent with low TOC values in this interval (Fig. 3). An alternative 
513 explanation is the formation of co-genetic, ${ }^{13} \mathrm{C}$-enriched, $\mathrm{CO}_{2}$ during methane formation.

514 Despite the evidence pointing to low lake levels at this time, methane formation in shallow 515 and eutrophic lakes has previously been reported in Mexico (Lake Pátzcuaro: Metcalfe et 516 al., 2007) and elsewhere (e.g. Lamb et al., 2000; Gu et al., 2004). The high concentrations 517 of $L$. sappaensis in this interval are consistent with the existence of a saline-alkaline lake 518 (Forester, 1986): interestingly, the peaks in ostracod abundance coincide broadly with the 519 peaks in $\delta^{18} \mathrm{O}_{\text {carb}}$, suggesting that ostracod numbers increased with salinity, and hence 520 evaporative enrichment. The occurrence of siliceous nodules within the interval, 521 associated with the levels that have the highest $\delta^{18} \mathrm{O}_{\text {carb }}$ values, is also consistent with the 522 existence of highly saline and alkaline water. The sporadic isotope values from ostracod 523 shells in this interval show ${ }^{18} \mathrm{O}$-enrichment compared with endogenic carbonates that is 524 broadly consistent with the approximate $+0.7 \%$ vital offset recorded for the genus 525 Limnocythere (von Grafenstein et al., 1999). In contrast, the carbon isotope values in 526 ostracod shells are similar to those in endogenic carbonate, suggesting that both sources 527 of carbonate precipitated from DIC with a similar $\delta^{13} \mathrm{C}$ value once allowance has been 528 made for differences in the timing and exact location of formation. This period covers 529 diatom zones YC2-I and part of YC2-II (Fig. 6). The base of the core is dominated by C. 530 muelleri, a diatom known to inhabit chloride-rich waters, but the other taxa here do not 531 indicate hypersaline conditions, so it may be over-represented. The most negative $\delta^{18} \mathrm{O}_{\text {carb }}$ 532 value may be reflected in the increase in the freshwater $N$. molestiformis and $N$. fluens 533 although the diatom assemblage overall continues to indicate shallow and alkaline 534 conditions. The presence of Nitzschia palea and a form of Nitzschia frustulum (both 535 obligate $\mathrm{N}$ heterotrophs) also indicates eutrophic conditions, which may help to explain 536 methanogenesis in shallow water conditions (see above). The increasing abundance of $N$. 537 elkab, and species of Anomoeoneis indicate more consistently high $\mathrm{pH}(>8.5)$ and 538 alkalinity, probably associated with shallowing of the lake. Low magnetic susceptibility and 
539 low concentrations of 'inwash' indicator elements ( $\mathrm{Fe}, \mathrm{Mn}, \mathrm{K}$ and $\mathrm{Al}$ ) in this interval

540 suggest that inwash of soil into the lake was limited despite the intervals of increased

541 effective moisture (Fig. 3).

543 Between $\sim 27,500$ and 14,000 aBP, there was a shift to more positive $\delta^{18} \mathrm{O}_{\text {carb }}$ and $\delta^{13} \mathrm{C}_{\text {carb }}$ 544 values, although with some stratigraphical variability and strong covariance between $545 \delta^{18} \mathrm{O}_{\text {carb }}$ and $\delta^{13} \mathrm{C}_{\text {carb }}$ (Fig.4, Fig. 5). The elevated $\delta^{18} \mathrm{O}_{\text {carb }}$ values suggest enhanced 546 evaporative enrichment of lake water under conditions of low effective moisture: the 547 presence of siliceous nodules at various points in this interval support the argument that 548 the lake was shallow, saline and strongly evaporated. Short-term variations in carbonate 549 content also support the occurrence of strong but variable evaporative enrichment (Fig. 3). 550 The presence of multiple surfaces that probably resulted from desiccation in the later part 551 of this interval suggests that lake levels fell and the lake may have dried out totally on 552 several occasions. Elevated $\delta^{13} \mathrm{C}_{\text {carb }}$ values are too high to be explained solely by 553 equilibration with atmospheric $\mathrm{CO}_{2}$. Enhanced aquatic productivity, in which ${ }^{12} \mathrm{C}$-uptake by 554 aquatic plants and algae causes DIC to be enriched in ${ }^{13} \mathrm{C}$, is incompatible with the low 555 TOC content in this interval: the production of ${ }^{13} \mathrm{C}$-enriched co-genetic $\mathrm{CO}_{2}$ in a stagnant, 556 shallow, nutrient-rich lake could provide an alternative explanation as discussed above. 557 From 27,500 to 22,500 aBP, a period of evaporative enrichment and periodic desiccation 558 is consistent with the diatom record for this interval (zones YC2-Ila and YC2-IIb), which 559 ends around 22,500 aBP in a period when diatoms were sparse and poorly preserved 560 (after which there is a break in diatom preservation, see above). There are two notable 561 peaks in N. minusculoides reaching $71 \%$ of the count between 27,000 and 26,000 aBP 562 and $44 \%$ at around 24,000 aBP. The earlier peak is associated with a layer of sand (or 563 tephra, see below) and, moreover, there are no stable isotope data from this layer, so its 564 significance remains unclear. The presence of some freshwater taxa (e.g. N. fluens, 
Caloneis bacillum) may reflect fluctuating conditions within a period of overall drying.

There are several marked peaks in ostracod abundance during this interval, with assemblages strongly dominated by Limnocythere sappaensis, which supports the inference that the lake was generally saline and alkaline. The sporadic occurrence of other taxa suggests the periodic influx of fresher waters: rather than whole-lake freshening, these taxa could indicate surface or subsurface inflow of fresh water at various times. Low magnetic susceptibility values and low concentrations of 'inwash' elements suggest limited transfer of soil or sediment from the catchment during this interval; two sharp peaks in magnetic susceptibility around 26,000 and 23,000 aBP (Fig. 3) may represent tephra, rather than catchment inwash, although this remains to be confirmed.

There is a gap in the stable isotope record between 14,000 and $11,000 \mathrm{aBP}$, but evidence for dry conditions during this interval comes from the presence of a desiccation surface and the occurrence of a possible palaeosol. It is also supported by the lack of diatom preservation. Sporadic ostracod occurrence also suggests that the lake may have been ephemeral during this time. This interval covers the northern hemisphere late glacial stadial event and confirms that this was a time of low effective moisture in central Mexico.

After $11,000 \mathrm{aBP}$, there was a shift to more negative and also more variable $\delta^{18} \mathrm{O}_{\text {carb }}$ and $\delta^{13} \mathrm{C}_{\text {carb }}$ values, consistent with a general increase in effective moisture during the early Holocene (Fig. 4). The rise in magnetic susceptibility, coupled with minor increases in some of the 'inwash' elements, may also reflect enhanced inwash of catchment material during the early Holocene. Diatom preservation resumes (zone YC2-III), with assemblages dominated by Nitzschia palea and Chaetoceros muelleri (Fig. 6). Assuming that $C$. muelleri may be overrepresented, high percentages of N. palea and Nitzschia communis indicate lower pH and TDS (total dissolved solids) (Gasse, 1986) and eutrophic conditions. 
591 This assemblage shows some similarities to that in zone YC2-la, but zone YC2-III may

592 represent the period when the lake was freshest and deepest, although not deep enough

593 to develop a truly planktonic flora. Today, assemblages with such high percentages of $N$.

594 palea are found in shallow, freshwater lakes in Mexico with high levels of nutrient

595 enrichment such as Lakes Zacapu and Cajititlan (Hill, 2006 and S. Metcalfe, unpublished

596 data). Ostracod concentrations are low, but significantly the assemblages include a

597 relatively high proportion of species other than L. sappaensis, consistent with fresher 598 water than in much of the pre-Holocene.

600 Between about 8,000 and 4,500 aBP there was a marked change in the lake system.

601 Increase in $\delta^{18} \mathrm{O}_{\text {carb }}$ values suggests enhanced evaporative enrichment associated with 602 decreased effective moisture (Fig. 4). Most notably, however, is the dramatic positive 603 excursion in $\delta^{13} \mathrm{C}_{\text {carb }}$ values, up to a maximum of about $+16 \%$ and, associated with this, 604 the breakdown in the positive covariance between $\delta^{18} \mathrm{O}_{\text {carb }}$ and $\delta^{13} \mathrm{C}_{\text {carb }}$ values that was 605 apparent during earlier intervals (Fig. 5). The very high $\delta^{13} \mathrm{C}_{\text {carb }}$ values are best explained 606 by methanogenesis, as discussed for earlier intervals above. Interestingly, the single $607 \delta \delta^{13} \mathrm{C}_{\text {ostracod }}$ value from this interval does not track the $\delta^{13} \mathrm{C}_{\text {carb }}$ values, but instead is much 608 lower (Fig. 4). Although we cannot attach too much significance to a single value, this 609 does suggest that the ostracods and the endogenic carbonate were formed in different 610 micro-environments within the lake, or perhaps during different seasons, from DIC with 611 contrasting $\delta^{13} \mathrm{C}$ values. Although the $\delta^{18} \mathrm{O}_{\text {ostracod }}$ values are more positive than the $\delta^{18} \mathrm{O}_{\text {carb }}$ 612 values, as would be expected, the difference is too large to be explained by vital offsets 613 alone, possibly lending support to the view that the endogenic and ostracod carbonates 614 were formed under contrasting conditions or at different times of the year. Ostracods occur 615 sporadically in this interval, indicating that whatever conditions prevailed were not wholly 616 unsuitable for ostracods to live. This period straddles the diatom record at the top of YC2 
617 (zone YC2-IV) and the bottom of YC1 (zone YC1-I). The diatom assemblage is notable for

618 its dominance by N. (C.) elkab and N. (C.) halophila (both cores), with Nitzschia frustulum

619 and N. palea (Fig. 6). The switch to an N. elkab/N. halophila flora is consistent with a

620 return to more alkaline conditions, probably driven by increasing evaporation. Navicula

621 (C.) elkab does seem to have a distinct ecology, with a preference for hyper-alkaline,

$622 \mathrm{Na}_{2} \mathrm{CO}_{3}$ lakes, where $\mathrm{Cl}^{-}$is also important. Nitzschia frustulum tends to be more abundant

623 with $N$. (C.) elkab than with $N$. (C.) halophila (e.g. YC2-4c and base of YC1-1) supporting

624 the interpretation of high alkalinity (Gasse, 1986). Its presence with N. palea again seems

625 to indicate high levels of nutrient enrichment. Overall, this assemblage is quite similar to

626 that sampled from the modern lake in 1982, when it was around 2 metres deep. A peak

627 in magnetic susceptibility between about 5,500 and 4,500 BP (Fig. 3) associated with a

628 sharp reduction in $\delta^{18} \mathrm{O}_{\text {carb }}$ (Fig. 4) points to a climatically-controlled inwash event, which

629 may be reflected by rather poor diatom preservation in YC1.

631 After 4,500 aBP, $\delta^{18} \mathrm{O}_{\text {carb }}$ remained high although with some short-lived negative

632 excursions, whereas $\delta^{13} \mathrm{C}_{\text {carb }}$ values are reduced dramatically (Fig. 4). For the interval of

633 overlap between YC1 and YC2, there is good agreement between the isotope records,

634 especially so for $\delta^{13} \mathrm{C}_{\text {carb}}$, once allowance is made for the slight age difference between the

635 two cores, as discussed earlier. There is a large increase in ostracod concentration within

636 much of this interval: the dominance of assemblages by L. sappaensis, coupled with the

637 large number of individuals, is consistent with the lake having been saline and alkaline for

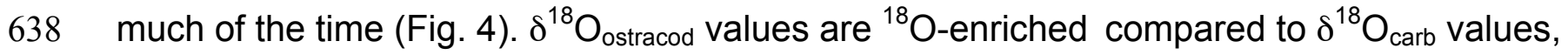

639 with the degree of enrichment consistent with vital offsets from oxygen-isotope equilibrium,

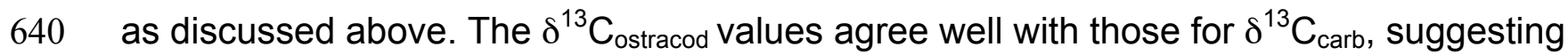

641 that the two sources of carbonate formed under the same set of conditions, as was the

642 case for the interval prior to the positive $\delta^{13} \mathrm{C}_{\text {carb }}$ excursion. The diatom record for this 
643 interval was published by Metcalfe and Hales (1994), although here we plot the data 644 against our new age model (Fig. 6). The species encountered confirm the presence of a 645 shallow alkaline lake throughout the late Holocene, although the balance between $\mathrm{CO}_{3}{ }^{2-}$ 646 and $\mathrm{Cl}^{-}$seems to have varied. The assemblage in zone YC1-II, for example, may indicate 647 that $\mathrm{Cl}^{-}$replaced $\mathrm{CO}_{3}{ }^{2-}$ as the dominant anion. The assemblage is similar to Bradbury's 648 (1989) saline marsh group. Fresher conditions were then re-established, associated with 649 inwash from the catchment. This wetter/drier cycle is then repeated in zones YC1-III and 650 YC1-IV. Increasingly hostile conditions for diatom preservation are indicated through zone 651 YC1-V, with only a patchy diatom record between about 2000 and 1200 aBP. It seems 652 likely that the single count available through this period is significantly affected by 653 differential preservation. The diatom record resumes around 1000 aBP with a distinctive, 654 well-preserved sample dominated (55\%) by Navicula muralis (zone YC1-VII). This diatom 655 is often found on mud flats and amongst aquatic vegetation (Hustedt, 1961-66). When combined with very low magnetic susceptibility values, the diatom assemblages indicate catchment stability. We note that this catchment stability occurs at a time in the late Classic when many sites in the relatively dry parts of Central Mexico were abandoned (Beekman, 2010; Park et al., 2010). The most recent sediments preserve a flora quite 660 similar to that found in the various surface sediment samples, indicating a shallow alkaline 661 lake, but with increasing nutrient levels. The very highly evolved chemistry and rather 662 distinctive diatom flora of La Piscina de Yuriria is described in Davies et al. (2002) and 663 sampling in 2003 and 2004 confirmed its hypereutrophic status. Phases of inwash, 664 previously reported in YC1 and attributed to anthropogenic disturbance (Metcalfe et al., 665 1994), are also seen at broadly the same times in YC2, i.e. around 3,600 and 1500 aBP 666 and over the past few centuries. An earlier phase at the base of $\mathrm{YC} 1$, which ended in that 667 core around 4700 aBP, appears in its entirety in YC2, starting around 5600 aBP. The 668 absence of Z. mays pollen from YC1 during this interval led Metcalfe et al. (1994) to 
suggest that the inwash was climatically-mediated rather than the result of anthropogenic disturbance. For the wider region however, Park et al. (2010) suggest that agricultural activity began as early as around $5700 \mathrm{aBP}$ (based on the presence of Zea pollen), and expanded around $3000 \mathrm{aBP}$. Lozano et al. (2013) also report the occurrence of Z. mays pollen from $3000 \mathrm{aBP}$ in Lake Zirahuen, a lake previously thought to be un-affected by human impact. The main climatic and environmental changes revealed in the records from La Piscina de Yuriria are summarised in Table 2.

There is a reasonable correspondence between phases of inwash, as indicated by magnetic susceptibility and 'inwash' elements, and intervals of low ostracod abundance for the whole of the Holocene (Fig. 7). This suggests that increased turbidity in the lake, which would likely have arisen during phases of increased inwash, was unfavourable for ostracod survival as has been noted previously (e.g. Bridgwater et al., 1999). Therefore water turbidity is an additional control to hydrochemistry on ostracod assemblages in La Piscina de Yuriria.

The number of palaeoclimatic records from the TMVB (and indeed the whole of Mexico), extending back to $30,000 \mathrm{BP}$ (Marine Isotope Stage 3) is small and limited to the Basin of Mexico (e.g. Caballero and Ortega-Guerrero, 1998; Roy et al., 2009; Lozano-García et al., 2015), Lake Cuitzeo (Israde et al., 2010), Lake Pátzcuaro (Watts and Bradbury, 1982; Bradbury 2000) and Lake Zacapu (Correa-Metrio et al., 2012). Moreover, most of these have limited dating control for the older sediments. Caballero et al. (2010) integrated palaeolimnological records with evidence from glacial chronologies (Vazquez Selem and Heine, 2004) to provide a palaeoclimatic scenario for the period from around 30,000 aBP to the last glacial maximum (LGM). A more recent consideration of the record from Lake Chalco in the Basin of Mexico has been published by Lozano-Garcia et al. (2015). With 
695 the exception of Lake Pátzcuaro (one of the westernmost sites), the records suggest

696 drying and cooling after about 30,000 aBP, with glacial advances restricted until around

69722,000 aBP. The data from La Piscina de Yuriria suggest that there were rapid shifts

698 between wet and dry conditions during this interval, with a general drying trend sometime

699 between about 27,500 and 25,000 aBP. However, the relatively low resolution of the

700 record after about 27,500 aBP means that a continuation of abrupt shifts in rainfall cannot

701 be ruled out. Major glacial advances in the TMVB occurred around the LGM $(22,000-$

$70218,000 \mathrm{aBP}$ ) with a suggested $6-8^{\circ} \mathrm{C}$ lowering in mean annual temperature. Reduced

703 temperature, along with low effective moisture, could have contributed to the elevated

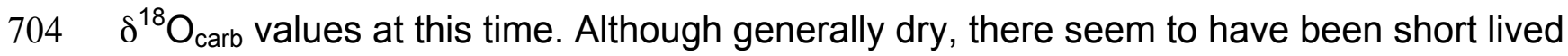

705 lake highstands in Cuitzeo and rising water levels in the Chalco Basin (southern Basin of

706 Mexico) and the Lerma Basin around 18,000 and 19,000 aBP respectively (Caballero et

707 al., 2002). Unfortunately the evidence from La Piscina de Yuriria is at too low resolution to

708 be able to detect these highstands. The late glacial in the TMVB $(18,000-15,000$ aBP $)$ is

709 described as cold and dry, with minor glacial recession (Caballero et al., 2010): evidence

710 from La Piscina de Yuriria indicates a continuation of dry conditions through the late glacial

711 (=Younger Dryas) stadial. Significant warming and glacial retreat apparently started

712 around 14,000 aBP.

714 Overall, the records of cool and dry conditions around the LGM and into the early

715 Holocene from the central and eastern part of the TMVB are most easily explained by a

716 reduction in summer season precipitation, which is driven today by the northward

717 movement of the ITCZ and the onset of the NAM. Records from the Pátzcuaro Basin, to

718 the west of this group, show high lake levels persisting through the LGM (Bradbury 2000;

719 Metcalfe et al., 2007), while Correa-Metrio et al. (2012) suggest conditions moist enough

720 for pine forest to dominate over grasslands in the Zacapu basin. In both cases an increase 
721 in winter precipitation may provide an explanation although it is hard to reconcile this with

722 the stable-isotope data from La Piscina de Yuriria, which suggest an overall decrease in

723 effective moisture. Lachniet et al. (2013) have further suggested that the summer

724 monsoon did not collapse during the last glacial, although once again the evidence from

725 La Piscina de Yuriria does not appear to support this, nor does the latest interpretation of 726 the Chalco record (Lozano-Garcia et al., 2015). The late glacial stadial was a time of dry 727 conditions, with some suggestion that La Piscina de Yuriria may have dried out. A dry

728 Younger Dryas stadial has also been reported from Zacapu (Correa-Metrio et al., 2012)

729 and from sites in northern Mexico (e.g. Roy et al., 2013). Interestingly, the Younger Dryas

730 is also reported as dry in the Juxtlahuaca speleothem record (Lachniet et al., 2013) where

731 it is attributed to monsoon collapse. It appears that the weakening of the Atlantic

732 Meridional circulation (AMOC), the subsequent southward displacement of the ITCZ and a 733 weaker monsoon led to dry conditions over the northern hemisphere neotropics (Bush and 734 Metcalfe, 2012). Only at the northern edge of the NAM region did the resumption of cold 735 conditions allow more penetration of mid-latitude westerlies leading to wetter conditions 736 (Metcalfe et al., 2015).

738 The classic pattern of climatic change in the $\mathrm{NH}$ tropics and subtropics is for wetter 739 conditions in the early Holocene driven by poleward migration of the ITCZ and a stronger 740 monsoon in response to insolation forcing. Whilst there is some support from this in 741 Mexico, it seems that the establishment of the modern climatic regime was delayed by the 742 presence of the residual Laurentide Ice Sheet and the influence of meltwater pulses 743 entering the Gulf of Mexico (Metcalfe et al., 2015). The early Holocene interval in La 744 Piscina de Yuriria indicates a change to wetter conditions overall, but with evidence for 745 abrupt shifts between wet and dry conditions. A similar pattern is recorded by Park et al. 746 (2010) for their other sites in the Valle de Santiago. The response of the wider NAM region 
747 to the insolation maximum in the early Holocene is complex, with the clearest response in

748 the south, where the direct influence of the ITCZ is strongest. Elsewhere, it seems that the 749 modern NAM regime may not have resumed until after 8000 aBP and there was a trade-

750 off between increasing precipitation and increasing temperatures (Metcalfe et al., 2015).

751 La Piscina de Yuriria shows an overall trend of drying from the mid Holocene onwards.

752 This is consistent with the southward migration of the ITCZ and as the role of insolation

753 forcing became weaker, so the effect of other climate forcings such as ENSO, seems to

754 have become more important giving rise to increasingly complex patterns of change. This

755 drying was accompanied by increasing human impact, as shown by evidence for phases

756 of sediment inwash and by the presence of Z. mays pollen. Increasing human impact

757 during this interval is also evident from other sites in Mexico (Metcalfe et al., 1994).

\section{Conclusions}

760 In summary, evidence from La Piscina de Yuriria indicates that the climate of Central

761 Mexican highlands has changed dramatically over the past $\sim 30,000$ years. Between

76230,000 and about 27,500 aBP it was highly variable with shifts, which may have been

763 abrupt, between dry and wet conditions. Over much of the glacial period, from $\sim 27,500$ to

764 about 14,000 aBP, climate became drier: there may have been abrupt shifts during this

765 interval, but the low resolution of our data means that any such shifts are not revealed.

766 The occurrence of strong millennial scale variability during MIS3, with a global signature,

767 has been widely noted (Clement and Peterson, 2008), apparently driven by changes in

768 AMOC. It is notable that there were three D/O warming events $(2-4)$ between 30,000 and 76922,000 aBP (Wolff et al., 2010) and two Heinrich events (H2 and H3). Modelling has

770 indicated differential sensitivity of AMOC under MIS3 and LGM conditions (e.g. Van

771 Meerbeeck et al. 2009), with the climate becoming less sensitive to AMOC changes as the

772 full glacial climate was established. The growth of the Laurentide Ice sheet from an 
773 interstadial minimum around 35,000 aBP to its maximum by ca. 25,000 aBP (where it 774 remained until around 15,000 aBP) (Dyke et al., 2002) also reflects the shift of the global 775 climate system into full glacial mode, where other, less rapid forcings may have dominated 776 (see Baker and Fritz, 2015). There is evidence of drought during the period that 777 encompassed the late glacial stadial. During the Holocene, the climate initially became 778 wetter, although the positive water balance was insufficient to lead to major changes in the 779 lake's chemistry and diatom flora. A fall in lake levels under drier climate in the mid 780 Holocene was accompanied by a change in limnology that caused methane formation. 781 Inwash of catchment soils and sediments was the result of a combination of natural 782 climatic triggers and, for the later Holocene, anthropogenic disturbance.

Acknowledgements

785 SEM and HLJ would like to acknowledge Professor Alayne Street-Perrott for introducing 786 them to Mexico and its many and varied lakes, including La Piscina de Yuriria. She led the Tropical Palaeoenvironments Research Group that took both the cores presented here and supervised the early work on these. We also acknowledge the pivotal role that the late Alan Perrott played in recovering lake-sediment cores from Mexico. Some of this work was funded by a University studentship from Kingston University to HLJ. We acknowledge support from NERC (radiocarbon dating allocation 549/0993 and stable isotope allocations IP/334/0992). Some of the sedimentological and geochemical analyses on core YC2 were undertaken by Nick Barber, formerly of University of Oxford. We thank Tim Heaton, NERC 794 Isotope Geosciences Laboratory, for isotope analyses of waters and ostracod shells. The geochemical results from YC1 were part of Philip Hales' DPhil thesis (supervised by ASP). SEM would like to acknowledge the work of her former student, Laura Park, for undertaking the initial diatom counts on YC2. 
References

801 Aharon P. 2003. Meltwater flooding events in the Gulf of Mexico revisited: implications for 802 rapid climate changes during the last deglaciation. Paleoceanography, 18: 1079, 803 doi:10.1029/2002PA000840

Alcocer J, Escobar E, Lugo A. 2000. Water use (and abuse) and its effects on the crater806 lakes of Valle de Santiago, Mexico. Lakes \& Reservoirs: Research \& Management, 807 5: $145-149$.

808

Aranda-Gómez JJ, Levresse G, et al. 2013, Active sinking at the bottom of the Rincón de

Parangueo Maar (Guanajuato, México) and its probable relation with subsidence faults at 811 Salamanca and Celaya. Boletín de la Sociedad Geológica Mexicana, 65: 169-188.

813 Baker PA, Fritz SC. 2015. Nature and causes of Quaternary climate variation of tropical 814 South America. Quaternary Science Reviews, 124: 31-47.

816 Barker P, Fontes J-C, Gasse F, Druart JC. 1994. Experimental dissolution of diatom silica 817 in concentrated salt solutions and implications for palaeoenvironmental reconstruction.

818 Limnology and Oceanography, 39: 99-110.

820 Battarbee, R.W. 1986. Diatom Analysis. In: Handbook of Holocene Palaeoecology and 821 Palaeohydrology [Berglund BE, (Ed.)] John Wiley \& Sons Ltd: New York; pp. 527-570. 822

823 Beekman CS. 2010. Recent research in Western Mexican archaeology. Journal of 824 Archaeological Research 18: 41-109. 
826 Bernal JP, Lachniet M, McCulloch M, Mortimer G, Morales P, Cienfuegos E. 2011. A

827 speleothem record of Holocene climate variability from southwestern Mexico. Quaternary

828 Research, 75: 104-113

830 Blaauw M. 2010. Methods and code for 'classical' age-modelling of radiocarbon

831 sequences. Quaternary Geochronology, 5: 512-518.

832

833 Bradbury JP. 1989. Late Quaternary lacustrine paleoenvironments in the Cuenca de

834 Mexico. Quaternary Science Reviews, 8: 75-100.

835

836 Bradbury JP. 2000 Limnologic history of Lago de Pátzcuaro, Michoacán, Mexico for the

837 past 48,000 years: impacts of climate and man. Palaeogeography Palaeoclimatology

838 Palaeoecology 63: 169-195.

839

840 Bridgwater ND, Heaton THE, O'Hara SL. 1999. A late Holocene palaeolimnological record

841 from central Mexico, based on faunal and stable-isotope analysis of ostracod shells.

842 Journal of Paleolimnology, 22: 383-397.

844 Brown RB. 1985. A summary of Late-Quaternary pollen records from Mexico west of the 845 Isthmus of Tehuantepec. In: Pollen Records of Late Quaternary North American 846 Sediments. [Bryant VM, Holloway RG. (Eds.)]. American Association of Stratigraphic 847 Palynologists: Dallas; pp. 71-92. 
849 Bush MB, Metcalfe SE, 2012 Latin America and the Caribbean. In: Quaternary 850 Environmental Change in the Tropics. [Metcalfe SE, Nash DJ. (Eds)]. J. Wiley \& Sons: 851 Chichester; pp. 263-311.

853 Butzer K, Butzer, EK. 1993. The sixteenth-century environment of the Central Bajio: 854 Archival reconstruction from Colonial land grants and the question of Spanish ecological 855 impact In: Culture, Form and Place. [Mathewson K. (Ed.)] Baton Rouge, LA, Geoscience 856 and Man 32: pp. 89-124.

858 Caballero M, Ortega-Guerrero B. 1998. Lake levels since 40,000 years ago at Chalco 859 Lake, near Mexico City. Quaternary Research, 50: 90-106.

861 Caballero, M, Ortega, B, Valadéz, F, Metcalfe, S, Macías, J, Sugiura, Y. 2002. Sta. Cruz 862 Atizapan: a 22-ka lake level record and climatic implications for the late Holocene human 863 occupation in the upper Lerma Basin. Palaeogeography, Palaeoclimatology, 864 Palaeoecology, 186: 217-235.

866 Caballero M, Lozano-García S, Vázquez-Selem L, Ortega B. 2010. Evidencias de cambio 867 climático y ambiental en registros glaciales y en cuencas lacustres del centro de México 868 durante el último máximo glacial. Boletín de la Sociedad Geológica Mexicana, 62: 359869377.

871 Clement AC, Peterson LC. 2008. Mechanisms of abrupt climate change of the last glacial 872 period. Reviews of Geophysics, 46, RG4002/2008. 
874 Cohen AS. 2003. Paleolimnology: the history and evolution of lake systems. Oxford 875 University Press: New York; 528 pp.

877 Correa-Metrio A, Lozano-Garcia S, Xelhuantzi-Lopez S, Sosa-Najera S, Metcalfe SE. 878 2012. Vegetation in western Central Mexico during the last 50,000 years: modern analogs 879 and climate in the Zacapu Basin. Journal of Quaternary Science, 27: 509-518.

881 Davies HL. 1995. Quaternary Palaeolimnology of a Mexican Crater Lake. Unpublished 882 PhD thesis, Kingston University.

884 Davies SJ. 2000. Environmental change in the west-central Mexican highlands over the 885 last 1,000 years: evidence from lake sediments. Unpublished PhD thesis, University of 886 Edinburgh.

888 Davies, SJ, Metcalfe, SE, Caballero, ME, Juggins, S. 2002. Developing diatom-based 889 transfer functions for Central Mexican lakes. Hydrobiologia, 467: 199-213.

891 De Deckker P, Forester RM. 1988. The use of ostracods to reconstruct 892 palaeoenvironmental records. In: Ostracods in the Earth Sciences. [De Deckker P, Colin J893 P, Peypouquet, J-P. (Eds.)] Elsevier: Amsterdam; pp.175-199.

895 Dean, W.E. 1974. Determination of carbonate and organic matter in calcareous sediments 896 and sedimentary rocks by loss of ignition: comparison with other methods. Journal of 897 Sedimentary Petrology. 44: 242-248. 
899 Dean WE, Gorham E. 1976. Major chemical and mineral components of profundal surface 900 sediments in Minnesota lakes. Limnology and Oceanography, 21: 259-284.

902 Decrouy L, Vennemann TW, Ariztegui D. 2011. Controls on ostracod valve geochemistry, 903 Part 1: variations of environmental parameters in ostracod (micro-) habitats. Geochimica et 904 Cosmochimica Acta, 75: 7364-7379.

905 Dyke AS, Andrews JT, Clark PU, England JH, Miller GH,Shaw J, Veillette JJ. 2002. The 906 Laurentide and Innuitian ice sheets during the Last Glacial Maximum. Quaternary Science 907 Reviews 21: 9-31.

909 Engstrom DR, Wright HEJ. 1984. Chemical stratigraphy of lake sediments as a record of 910 environmental change. In: Lake Sediments and Environmental History. [Haworth Y, Lund 911 E. (Eds.)]. Leicester University Press: Leicester; pp. 11-67.

913 Eugster HP, Hardie LA. 1978. Saline Lakes. In: Lakes: Chemistry, Geology, Physics. 914 [Lerman A. (Ed.)]. Springer-Verlag: New York; pp. 237-294.

916 Forester RM. 1986. Determination of the dissolved anion composition of ancient lakes 917 from fossil ostracodes. Geology, 14: 796-798.

919 Gasse, F., 1986. East African Diatoms. Taxonomy, ecological distribution. Bibliotheca 920 Diatomologica. 11: J. Cramer: Stuttgart; 202 pp.

922 Gasse F, Barker P, Gell PA, Fritz SC, Chalié, F. 1997. Diatom-inferred salinity in 923 palaeolakes: an indirect tracer of climate change. Quaternary Science Reviews, 16: 547924563. 
926 Goldsmith JR, Graf DL, and Heard HC. 1961. Lattice Constants of the Calcium927 Magnesium Carbonates. American Mineralogist, 43: 84-101.

929 Goman M, Byrne R. 1998. A 5000-year record of agriculture and tropical forest clearance 930 in the Tuxtlas, Veracruz, Mexico. The Holocene 8: 83-89.

932 Gomez de Orozco, F. 1972. Cronícas de Michoacán. UNAM: Mexico; 214 pp.

934 Gorenstein S, Pollard HP. 1983. The Tarascan civilisation: a late Prehispanic cultural 935 system. Publications in Anthropology 28: Vanderbilt University Press, Nashville, 936 Tennessee. 199 pp.

938 Grimm EC. 1987. CONISS: a FORTRAN 77 program for stratigraphically constrained 939 cluster analysis by the method of incremental sum of squares. Computers and 940 Geoscience, 13: 13-35

942 Gu B, Schelske CL, Hodell DA. 2004. Extreme ${ }^{13} \mathrm{C}$ enrichment in a shallow hypereutrophic 943 lake: implications for carbon cycling. Limnology and Oceanography, 49: 1152-1159.

945 Hill MO. 1979. TWINSPAN: A FORTRAN program for arranging multivariate data in an 946 ordered two-way table by classification of the individuals and attributes. Ecology and 947 Systematics, Cornell University: New York; 48 pp.

949 Hill E. 2006. Quantitative reconstruction of eutrophication histories in Central Mexican 950 lakes. Unpublished PhD thesis, University of Nottingham. 
952 Hustedt, F., 1961-1966. Die Kieselalgen Deutschlands, Österreichs und der Schweiz, Vol.

953 3. Reprinted 1977, Otto Koeltz: Koenigstein; 816 pp.

954

955 Israde Alcántara I, Velázquez-Duran R, Lozano García MS, Bischoff J, Dominquez

956 Vázquez G, Garduño Monroy VH. 2010. Evolución paleolimnológica del Lago Cuitzeo,

957 Michoacán durante el Pleistoceno-Holoceno. Boletin de la Sociedada Geologica

958 Mexicana, 62: 345-357.

959

960 Jongman RHG, ter Braak CJF, Van Tongeren OFR (Eds.) 1992. Data Analysis in

961 Community Ecology and Landscape Ecology. Cambridge University Press: Cambridge;

962324 pp.

963

964 Kienel U, Wulf Bowen S, Byrne R, Park J, Bohnel H, Dulski P, Luhr JF, Siebert L, Haug $965 \mathrm{GH}$, Negendank JFW, 2009. First lacustrine varve chronologies from Mexico: impact of 966 droughts, ENSO and human activity since AD 1840 as recorded in maar sediments from 967 Valle de Santiago. Journal of Paleolimnology, 42: 587-609.

968

969 Kilham P, Kilham SS, Hecky RE. 1986. Hypothesized resource relationships among

970 African planktonic diatoms. Limnology and Oceanography, 31: 1169-1181.

972 Krammer K. Lange-Bertalot H. 1988. Süsswasserflora von Mitteleuropa.

973 Bacillariophyceae. 2. Teil: Epithemiaceae, Bacillariaceae, Surirellaceae. Vol. 2/2. Gustav 974 Fischer Verlag: Stuttgart; 596 pp. 
Krammer K. Lange-Bertalot H. 1991a. Süsswasserflora von Mitteleuropa.

Bacillariophyceae. 3. Teil: Centrales; Fragilariaceae, Eunotiaceae. Vol. 2/3. Gustav

Fischer Verlag: Stuttgart; 576 pp.

Krammer K. Lange-Bertalot H. 1991b. Süsswasserflora von Mitteleuropa.

Bacillariophyceae. 4. Teil: Achnanthaceae. Vol. 2/4. Gustav Fischer Verlag: Stuttgart; 437 $\mathrm{pp}$.

Lachniet MS, Asmerom Y, Bernal JP, Polyak VJ, Vazquez-Selem L. 2013. Orbital pacing and ocean circulation-induced collapses of the Mesoamerican monsoon over the past 22,000 y. Proceedings of the National Academy of Sciences, 110: 9255-9260.

Lamb AL, Leng MJ, Lamb HF, Ummer M. 2000. A 9000-year oxygen and carbon isotope record of hydrological change in a small Ethiopian crater lake. The Holocene, 10: 167-177.

Lozano-García S, Vázquez-Selem L. 2005. A high-elevation Holocene pollen record from Iztaccíhuatl volcano, central Mexico. The Holocene, 15: 329-338.

Lozano-García, S., Sosa-Nájera, S., Sugiura, Y. and Caballero, M. 2005. 23,000 yr of vegetation history of the Upper Lerma, a tropical high-altitude basin in Central Mexico. Quaternary Research 64, 70-82.

98 Lozano-Garcia S, Torres-Rodríguez E, Ortega B, Vázquez G, Caballero M. 2013. Ecosystem responses to climate and disturbances in western central Mexico during the late Pleistocene and Holocene. Palaeogeography Palaeoclimatologyy Palaeoecology, 370: 184-195. 
1003 Lozano-Garcia S, Ortega B., Roy P, Beramendi-Orosco L, Caballero, M. 2015. Climatic

1004 variability in the northern sector of the American tropics since the latest MIS3. Quaternary

1005 Research, 84: 262-271.

1006

1007 Martens K. 1994. Summary of the morphology, taxonomy and distribution of Limnocythere 1008 inopinata (Baird, 1843) (Ostracoda, Limnocytheridae). In; The evolutionary ecology of 1009 reproductive modes in non-marine Ostracoda. [Horne DJ, Martens K. (Eds.)]. The

1010 University of Greenwich Press: Greenwich; pp. 17-22.

1011

1012 Metcalfe SE. 1990. Navicula elkab O. Müller - a species in need of redefinition? Diatom 1013 Research, 5: 419-423.

1014

1015 Metcalfe SE, Street-Perrott FA, Brown RB, Hales PE, Perrott RA, Steininger FM. 1989.

1016 Late Holocene Human Impact on Lake Basins in Central Mexico. Geoarchaeology, 4: 1191017141.

1018

1019 Metcalfe SE, Hales PE. 1994. Holocene Diatoms From A Mexican Crater Lake : La

1020 Piscina De Yuriria. Memoirs of the California Academy of Sciences, 17: 501-515.

1022 Metcalfe SE, Street-Perrott FA, O’Hara SL, Hales PE, Perrott RA (1994) The

1023 palaeolimnological record of environmental change: examples from the arid frontier of

1024 Mesoamerica. In: Environmental Change in Drylands: Biogeographical and

1025 Geomorphological Perspectives. [Millington AC, Pye K. (eds.)]. John Wiley and Sons Ltd:

1026 Chichester; pp.131-145 
1028 Metcalfe SE, Davies SJ, Braisby JD, Leng MJ, Newton AJ, Terrett NL, O'Hara SL. 2007.

1029 Long and short-term change in the Patzcuaro Basin, central Mexico. Palaeogeography

1030 Palaeoclimatologyy Palaeoecology, 247: 272-295.

1031

1032 Metcalfe SE, Barron JA, Davies SJ. 2015. The Holocene history of the North American

1033 Monsoon: 'known knowns' and 'known unknowns' in understanding its spatial and

1034 temporal complexity. Quaternary Science Reviews, 120: 1-27.

1035

1036 Ordoñez E. 1900. Les volcans du Valle de Santiago. Memorias de la Sociedad Cientifica

1037 Antonio Alzate (Mexico) 14: 299-326.

1038

1039 Park LA. 1999. Late Quaternary environmental change in La Piscina de Yuriria, Central

1040 Mexico: evidence from the palaeolimnological record. Unpublished MRes thesis,

1041 University of Edinburgh.

1042

1043 Park J, Byrne R, Bohnel H, Molina Garza R, Conserva M. 2010. Holocene climate change

1044 and human impact, central Mexico: a record based on maar lake pollen and sediment 1045 chemistry. Quaternary Science Reviews, 29: 618-632.

1046

1047 Patrick R. Reimer C.W. 1966. The diatoms of the United States exclusive of Alaska and

1048 Hawaii. Vol. 1. The Academy of Natural Sciences of Philadelphia, Philadelphia,

1049 Monograph, 13: 668 pp.

1050

1051 Patrick, R. \& C. W. Reimer, 1975. The diatoms of the United States exclusive of Alaska

1052 and Hawaii. Vol. 2. Part 1. The Academy of Natural Sciences of Philadelphia, Philadelphia,

1053 Monograph, 13: 213 pp. 
1055 Reimer PJ, Bard E, Bayliss A, Beck JW, Blackwell PG, Ramsey CB, Buck CE, Cheng H, 1056 Edwards RL, Friedrich M, Grootes PM, Guilderson TP, Haflidason H, Hajdas I, Hatte, 1057 C, Heaton TJ, Hoffmann DL, Hogg AG, Hughen KA, Kaiser KF, Kromer B, Manning SW, 1058 Niu M, Reimer RW, Richards DA, Scott EM, Southon JR, Staff RA, Turney CSM, van der 1059 Plicht J. 2013. Intcal13 and Marine13 Radiocarbon Age Calibration Curves 0-50,000 Years 1060 Cal BP. Radiocarbon, 55: 1869-1887.

1061

1062 Roy PD, Caballero M, Lozano R, Pi T, Morton O. 2009. Late Pleistocene-Holocene 1063 geochemical history inferred from Lake Tecocomulco sediments, Basin of Mexico, Mexico. 1064 Geochemical Journal, 43: 49-64.

1065

1066 Roy PD, Quiroz-Jimenez JD, Perez-Cruz L, Lozano-Garcia S, Metcalfe SE, Lozano1067 Santacruz R, Lopez-Balbiaux N, Sanchez-Zavala JL, Romero FM. 2013. Late Quaternary 1068 paleohydrological conditions in the drylands of northern Mexico: a summer precipitation 1069 proxy record of the last 80 cal ka BP. Quaternary Science Reviews, 78: 342-354.

1070

1071 Schoeman FR, Archibald REM. 1977. The Diatom Flora of South Africa, Nos. 1-6. CSIR 1072 Special Report WAT 50. Pretoria.

1073

1074 Sears PB, Clisby K. 1955. Palynology in southern North america, Part IV: Pleistocene 1075 climate in Mexico. Bulletin of the Geological Society of America, 66: 521-530.

1076

1077 Talbot MR. 1990. A review of the palaeohydrological interpretation of carbon and oxygen 1078 isotope ratios in primary lacustrine carbonates. Chemical Geology (Isotope Geosciences 1079 Section), 80: 261-279. 
1081 Tarutani T, Clayton RN, Mayeda TK 1969. The effect of polymorphism and magnesium

1082 substitution on oxygen isotope fractionation between calcium carbonate and water.

1083 Geochimica et Cosmochimica Acta, 33, 987-996.

1084

1085 ter Braak CJF. 1988a. CANOCO - a FORTRAN program for canonical community

1086 ordination by [partial] [detrended] [canonical] correspondence analysis, principal

1087 components analysis and redundancy analysis (version 2.1). Report LWA-88-02.

1088 Agricultural Mathematics Group: Wageningen.

1089

1090 Van Meerbeeck CJ, Renssen H, Roche DM. 2009. How did Marine Isotope Stage 3 and

1091 Last Glacial Maximum climates differ? - perspectives from equilibrium simulations.

1092 Climate of the Past, 5: 33-51.

1093

1094 Vazquez-Selem L, Heine, K. 2004 Late Quaternary glaciation in Mexico. In: Quaternary 1095 Glaciations - Extent and Chronology. Part III South America, Asia, Africa, Australia, 1096 Antarctica. [Ehlers J, Gibbard P. (Eds.)] Elsevier: Amsterdam; pp. 233-242.

1098 von Grafenstein U, Erlernkeuser H, Trimborn P. 1999. Oxygen and carbon isotopes in 1099 modern fresh-water ostracod valves: assessing vital offsets and autecological effects of 1100 interest for palaeoclimate studies. Palaeogeography Palaeoclimatology Palaeoecology, 1101 148: 133-152.

1103 Watts WA, Bradbury JP 1982. Late Pleistocene and Holocene paleoenvironments and 1104 human activity in the West-Central Mexican Plateau - evidence from Lake Pátzcuaro, 1105 Michoacán, and from the Cuenca de Mexico. Quaternary Research, 17: 56-70. 
1107 Wolff EW, Chappellaz J, Blunier T, Rasmussen SO, Svensson A. 2010. Millennial-scale

1108 variability during the last glacial: the ice core record. Quaternary Science Reviews, 29:

$1109 \quad 2828-2838$.

1110

1111

1112 Figures

1113

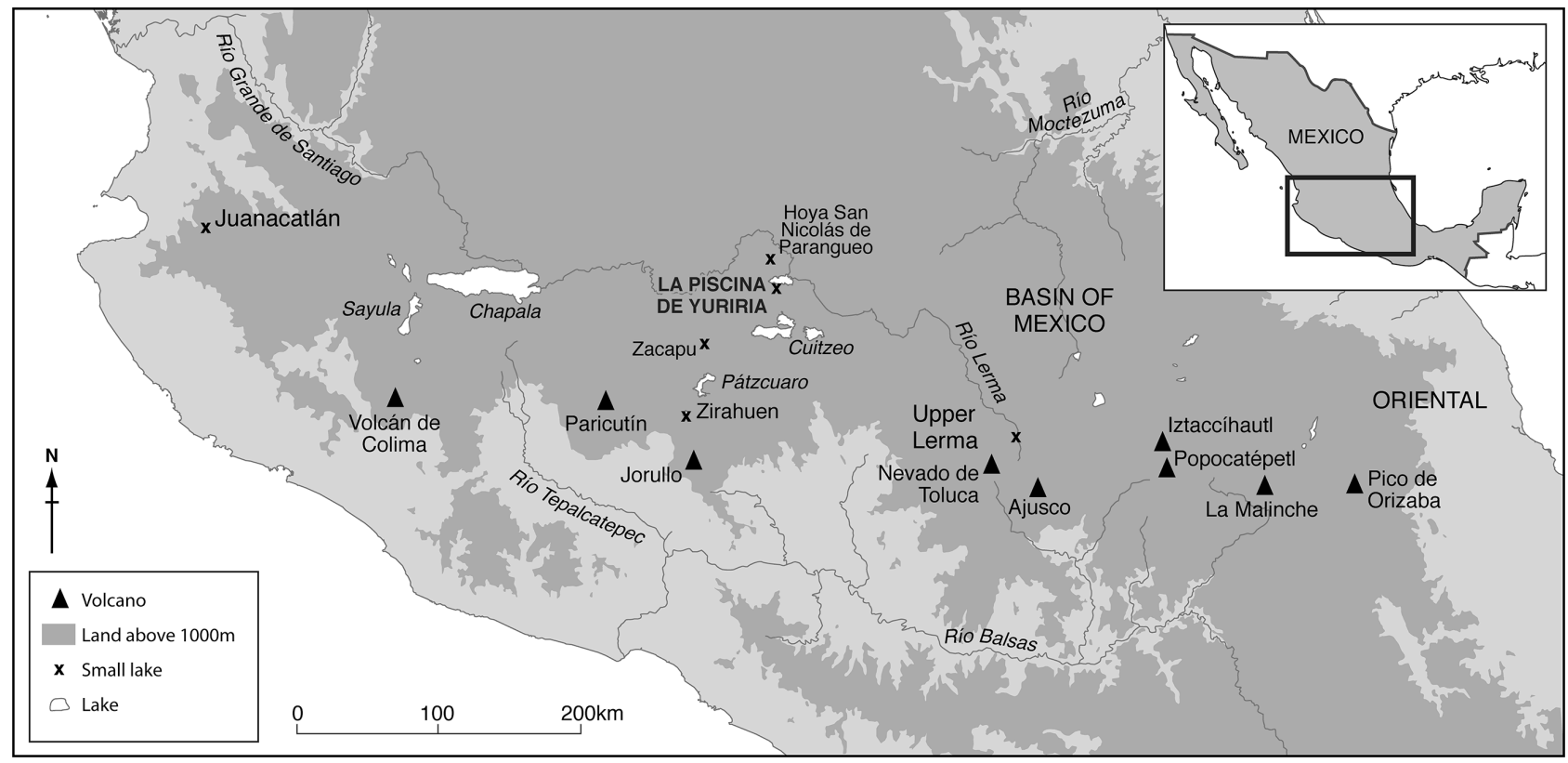

1114 Fig. 1. Location of la Piscina de Yuriria and other sites referred to in the text. 

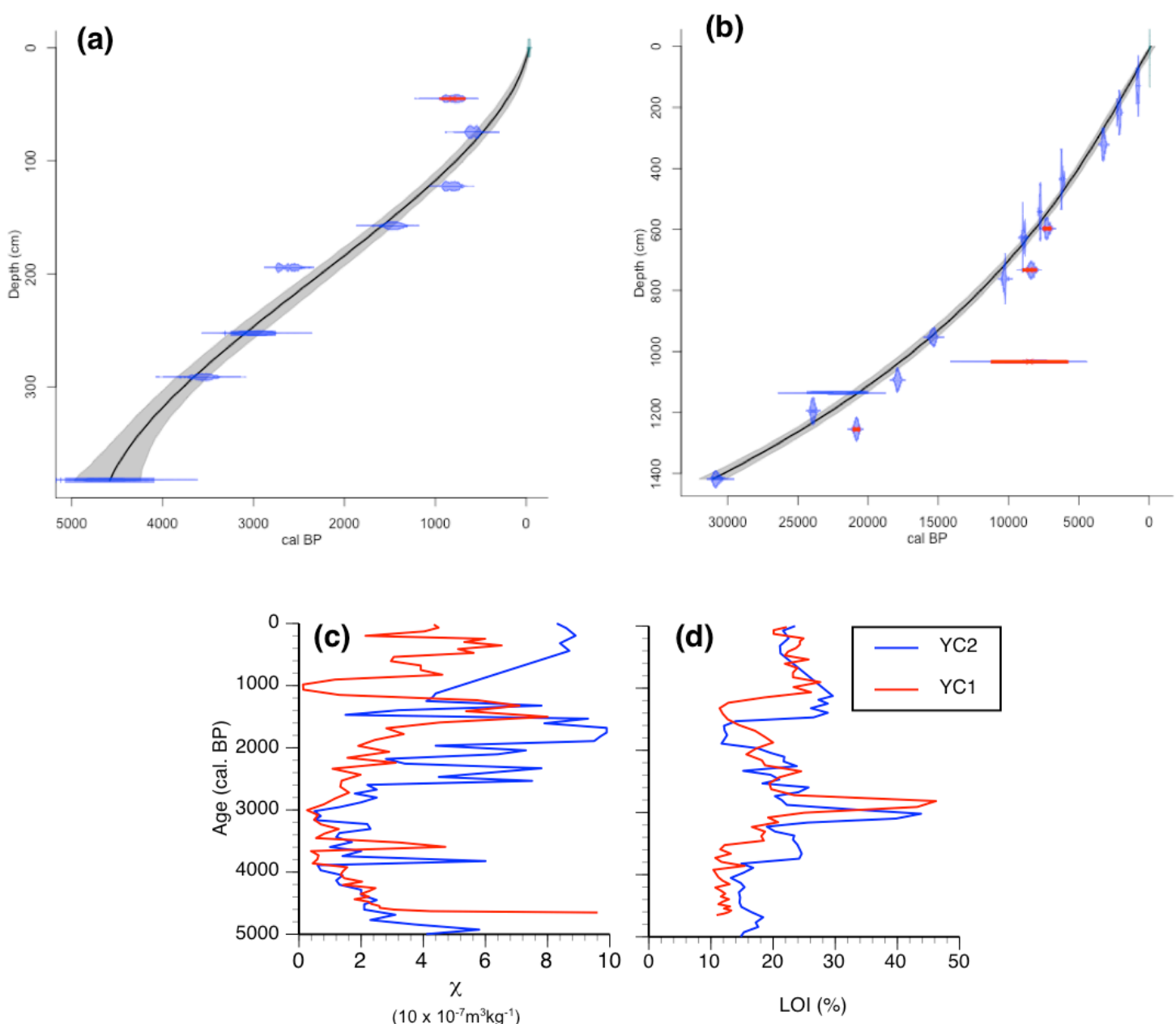

1116 Fig. 2. Age-depth relationships for (a) YC1 (b) YC2, based on radiocarbon dates. The

1117 datapoints are well described by 3rd order polynomial curves, AGE $=-0.0001$ Depth $^{3}+$

$11180.06645 D_{\text {Depth }}^{2}+2.473$ Depth -29.23 for YC1 and, AGE $=-0.000005 D_{\text {epth }}^{3}-$

1119 0.0006Depth ${ }^{2}+12.23$ Depth -109.1 for YC2 where age is in calendar years BP and depth 1120 is in $\mathrm{cm}$ in both cases. Detailed synchronisation for YC1 and the upper part of YC2 based 1121 on (c) loss-on-ignition and (d) magnetic susceptibility. 


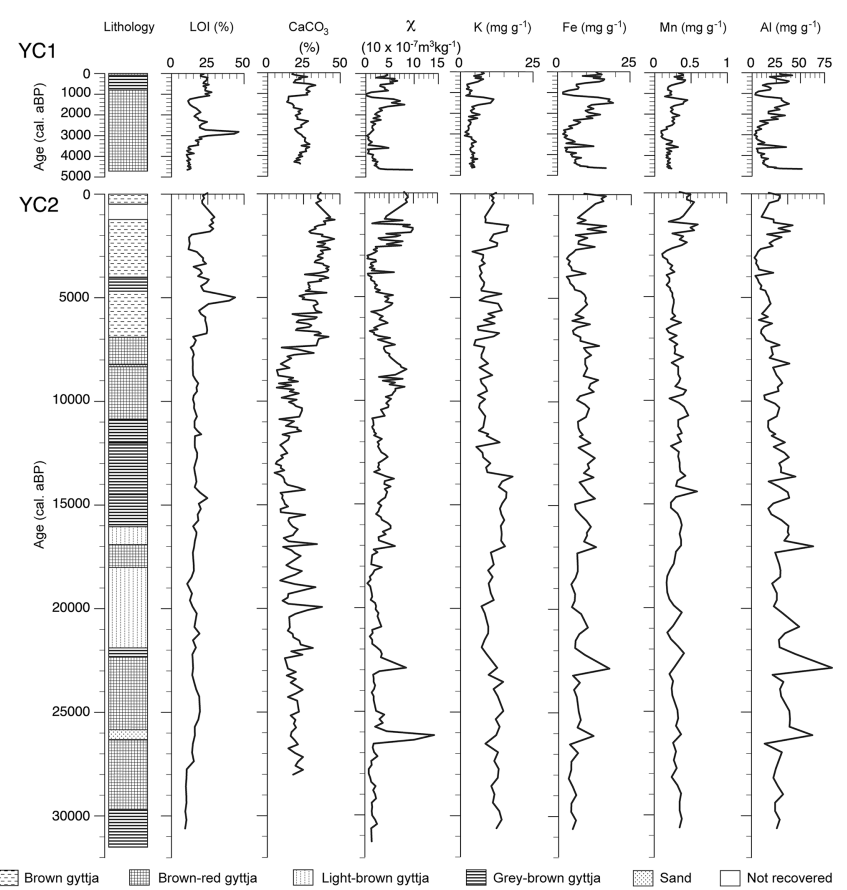

1123 Fig 3. Physical sedimentology and selected elemental geochemical variables for YC1 and 1124 YC2, plotted as a function of age in calendar years.
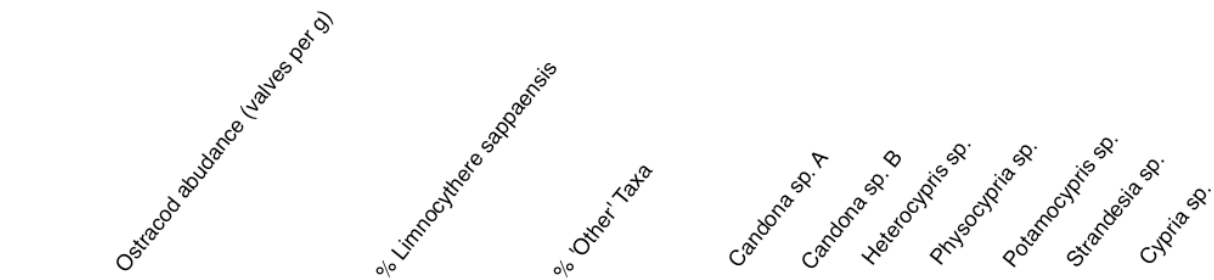

$\delta^{18} \mathrm{O}(\%)$

$\delta^{13} \mathrm{C}(\%)$
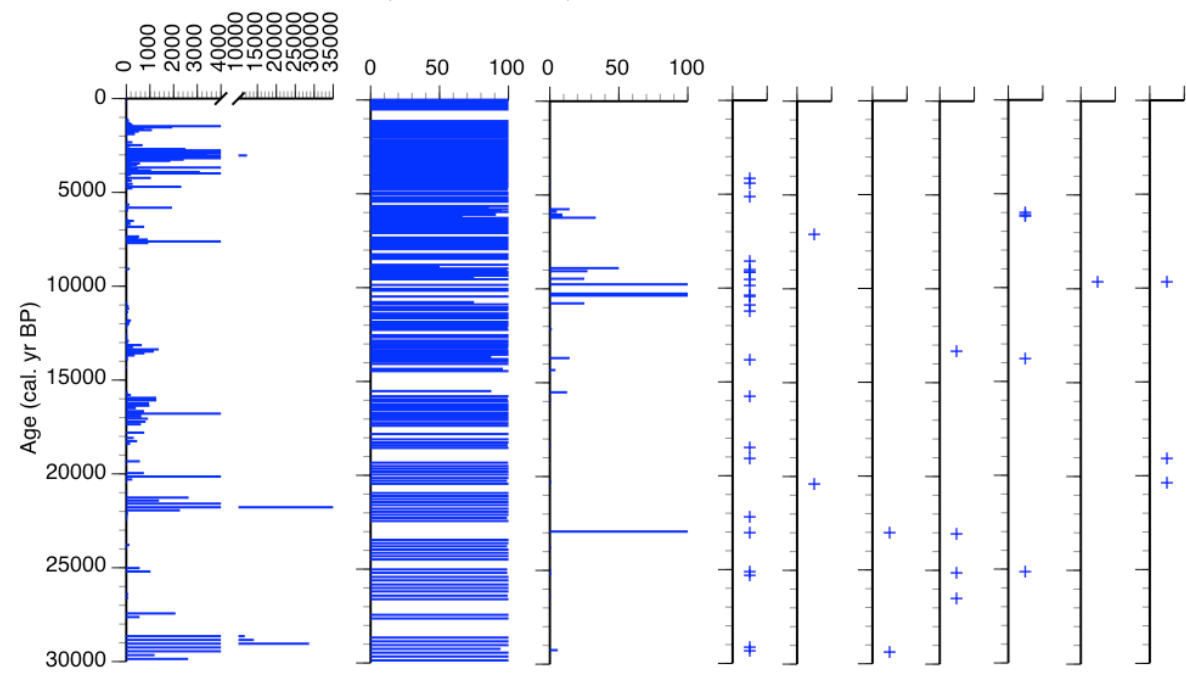

$\begin{array}{llllllllllll}-15 & -11 & -7 & -3 & 1 & 5 & -4 & 0 & 4 & 8 & 12 & 16\end{array}$

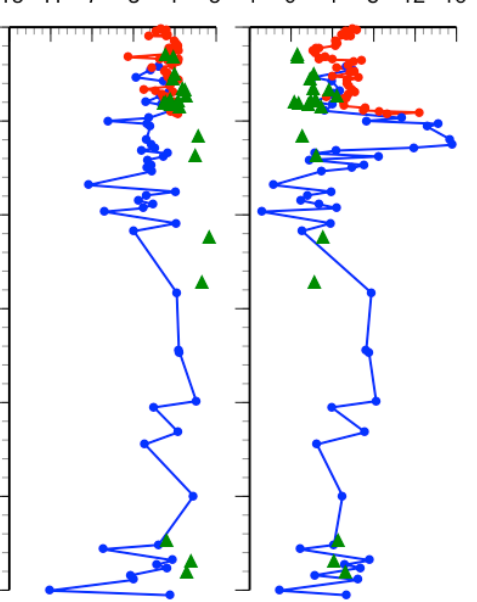

1126 Fig. 4. Ostracod assemblages for YC2 and stable isotopes: endogenic carbonate for YC1

1127 and YC2 and ostracod shells (triangles) for YC2). The 'other taxa' percentage curve 1128 includes all taxa except Limnocythere sappaensis. 


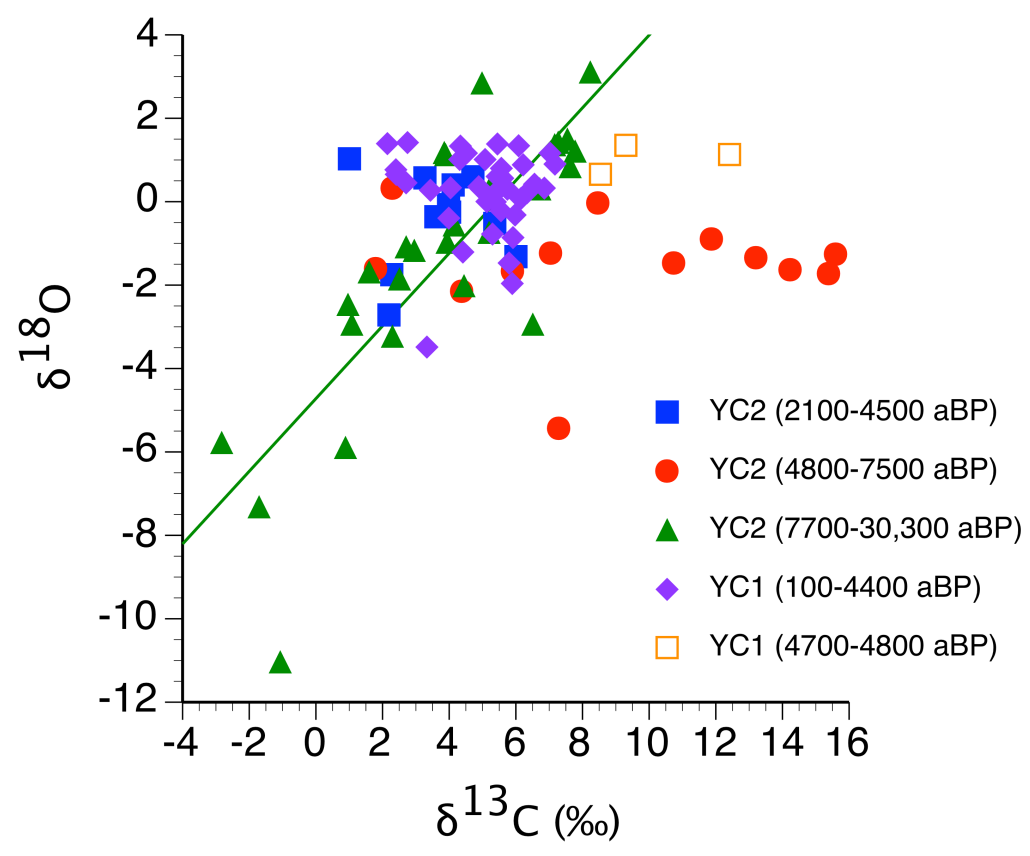

1130

1131 Fig. 5. Covariance of $\delta^{18} \mathrm{O}_{\text {carb }}$ and $\delta^{13} \mathrm{C}_{\text {carb }}$ values for $\mathrm{YC} 1$ and $\mathrm{YC}$. For the interval $\mathrm{YC2}$

$11327700-30,300$ aBP only, there is significant covariance between $\delta^{18} \mathrm{O}_{\text {carb }}$ and $\delta^{13} \mathrm{C}_{\text {carb }}$ values $1133 \quad\left(R^{2}=0.68\right)$.

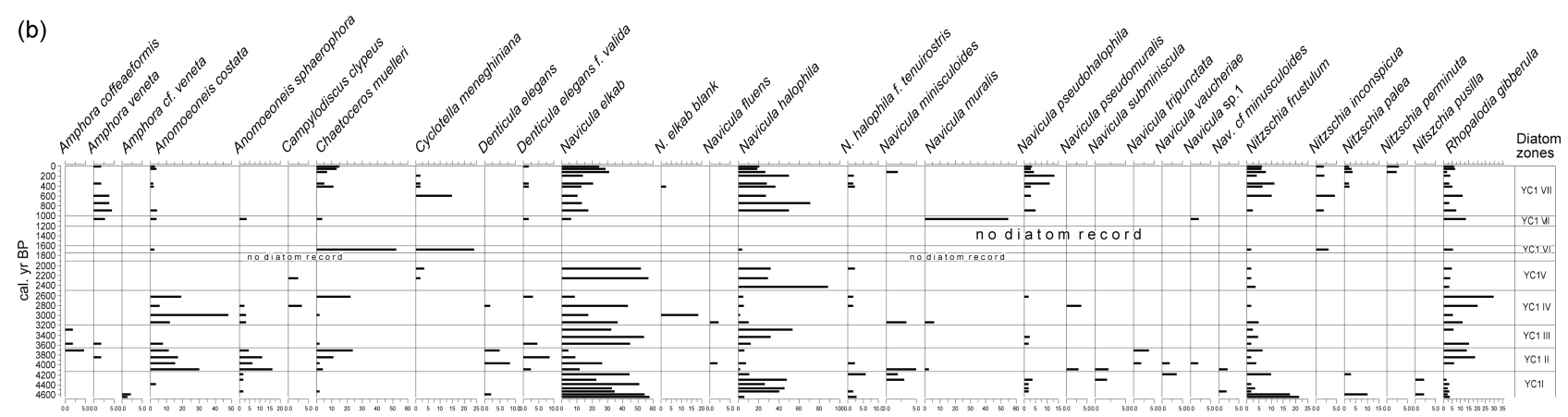

(a)

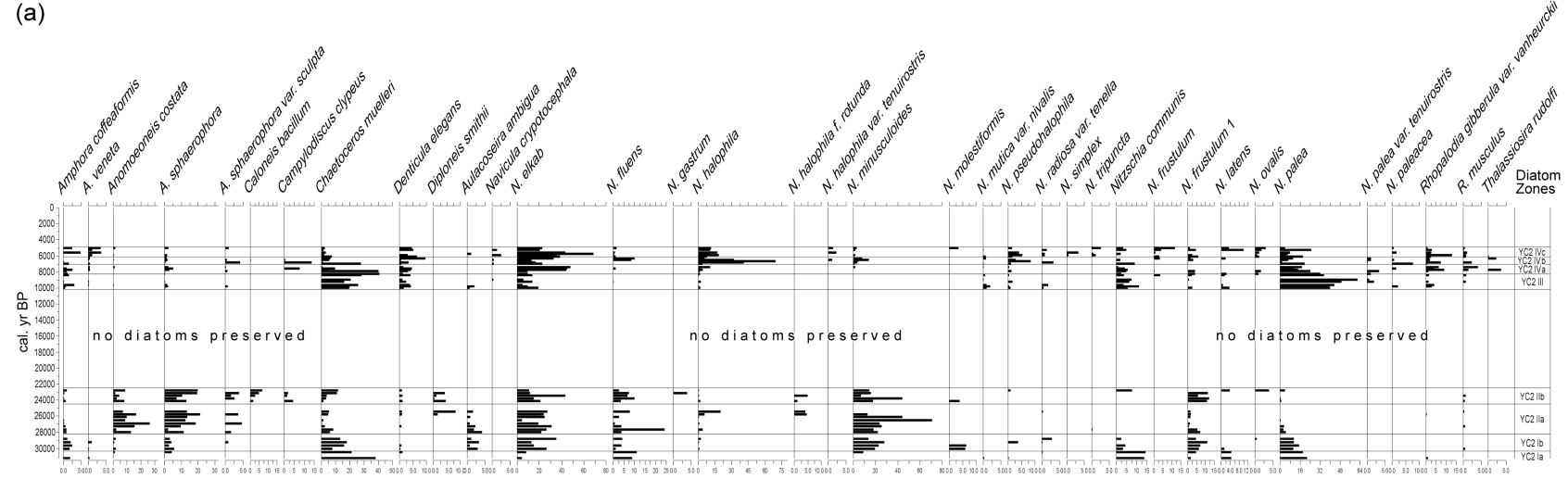

1135 Fig. 6. Diatom abundance (\%) for (a) YC2 and (b) YC1. Only taxa present at $>2 \%$ and in 1136 more than one sample are plotted. 


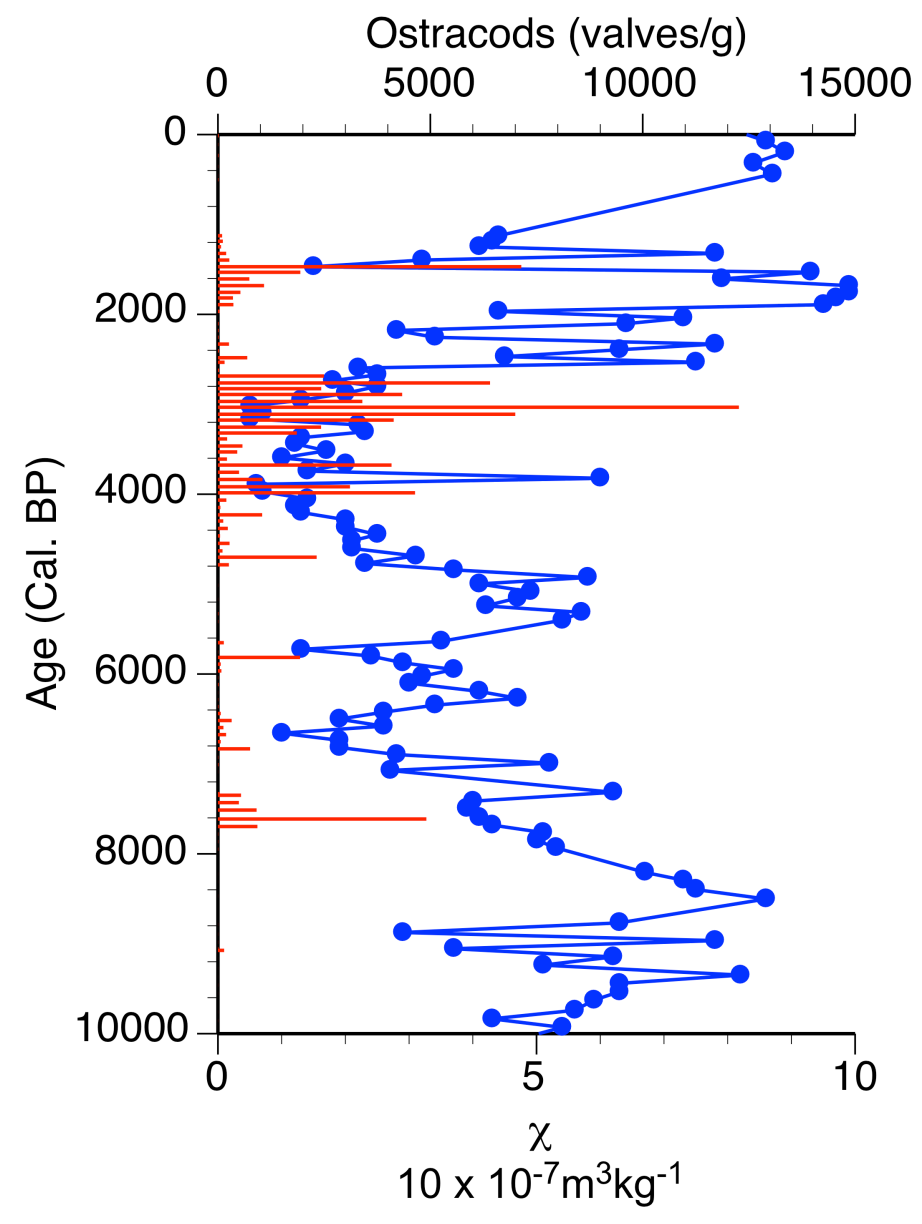

1137

1138 Fig. 7. Ostracod abundance and magnetic susceptibility for the last 10,000 years in core

1139 YC2.

1140

1141

1142

1143

1144

1145

1146

1147

1148

1149 


\section{Tables}

1151 Table 1. Radiocarbon dates from cores YC1 and YC2.

Table 1. Radiocarbon dates from cores YC1 and YC2

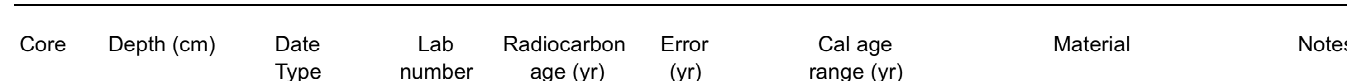

(95\% confidence intervals)

\begin{tabular}{|c|c|c|c|c|c|c|c|c|c|}
\hline YC1 & $44-46$ & AMS & OxA-1963 & 875 & 90 & 670 & 951 & carbonate & omitted from age model \\
\hline YC1 & $74-75$ & AMS & OxA-1964 & 570 & 80 & 500 & 673 & carbonate & \\
\hline YC1 & $122-123$ & AMS & OxA-1965 & 900 & 60 & 705 & 927 & carbonate & \\
\hline YC1 & $157-158$ & AMS & OxA-1966 & 1570 & 80 & 1307 & 1680 & carbonate & \\
\hline YC1 & $194-195$ & AMS & OxA-1967 & 2540 & 60 & 2383 & 2759 & carbonate & \\
\hline YC1 & $250-255$ & AMS & RIDDL-62 & 2840 & 120 & 2751 & 3323 & carbonate & \\
\hline YC1 & $291-292$ & AMS & OxA-1968 & 3320 & 90 & 3372 & 3824 & carbonate & \\
\hline YC1 & $380-385$ & AMS & RIDDL-63 & 4100 & 200 & 4084 & 5278 & carbonate & \\
\hline YC2 & $129-130$ & AMS & AA13908 & 860 & 50 & 689 & 908 & bulk organic carbon & \\
\hline YC2 & $216-217$ & AMS & AA13907 & 2125 & 50 & 1955 & 2306 & bulk organic carbon & \\
\hline YC2 & $321-322$ & AMS & AA13906 & 3040 & 70 & 3008 & 3391 & bulk organic carbon & \\
\hline YC2 & $430-440$ & Radiometric & SRR-5189 & 5410 & 50 & 6018 & 6300 & bulk organic carbon & \\
\hline YC2 & $537-547$ & Radiometric & SRR-5190 & 6925 & 45 & 7670 & 7911 & bulk organic carbon & \\
\hline YC2 & $592-602$ & Radiometric & 2815-Ors & 6340 & 140 & 6939 & 7552 & bulk organic carbon & omitted from age model \\
\hline YC2 & $622-632$ & Radiometric & SRR-5191 & 8055 & 50 & 8730 & 9120 & bulk organic carbon & \\
\hline YC2 & $728-738$ & Radiometric & 2844-Ors & 7570 & 188 & 8001 & 8967 & bulk organic carbon & omitted from age model \\
\hline YC2 & $761-762$ & AMS & AA13905 & 9105 & 80 & 9969 & 10511 & bulk organic carbon & \\
\hline YC2 & $953-954$ & AMS & AA13904 & 12865 & 105 & 15085 & 15728 & bulk organic carbon & \\
\hline YC2 & $1029-1039$ & Radiometric & 2812-Ors & 7100 & 1200 & 5752 & 11244 & carbonate & omitted from age model \\
\hline YC2 & $1093-1094$ & AMS & AA13903 & 14705 & 105 & 17617 & 18165 & bulk organic carbon & \\
\hline YC2 & $1130-1140$ & Radiometric & 2869-Ors & 18180 & 980 & 19938 & 24375 & bulk organic carbon & \\
\hline YC2 & $1190-1200$ & Radiometric & SRR-5192 & 19880 & 75 & 23676 & 24160 & bulk organic carbon & \\
\hline YC2 & $1250-1260$ & Radiometric & SRR-5193 & 17275 & 90 & 20577 & 21103 & bulk organic carbon & omitted from age model \\
\hline YC2 & $1413-1423$ & AMS & AA16907 & 26590 & 280 & 30308 & 31189 & bulk organic carbon & \\
\hline
\end{tabular}

1152

1153

1154

1155

1156

1157

1158

1159

1160

1161

1162

1163

1164

1165 
1166 Table 2. Summary of climatic and environmental changes at La Piscina de Yuriria over the

1167 past 30,000 years

Table 2. Summary of climatic and environmental changes at La Piscina de Yuriria over the past 30,000 years

Age Range (cal. aBP) Climatic and environmental conditions Key evidence

0-4,500 Lower effective mositrue under dier climate regime but with Oxygen isotopes

short-lived wetter intervals

Saline -alkaline lake

Transient anthropogenically-induced inwash events associated with catchment instability

$4,500-8,000$

$8,000-11,000$

$14,000-25,500$

$27,500-30,000$

Reduced effective moisture leading to enhanced evaporative enrichment under drier climate

Intense methane formation under wetter but variable climatic regime

Fresher and deeper lake, but eutrophic

Dry climate, lake dessication

Reduced effective moisture leading to enhanced evaporative enrichment under drier climate

Periodic lake desiccation

Saline - alkaline lake with short-lived fresher intervals

Shallow eutropic lake with methane formation

Stable catchment with limited inwash
Saline - alkaline lake with nutrient enrichment and shortlived fresher interval

Climatically-contorlled inwash event during wet intervals

Higher effective moisture, but with evidence of variability

Rapid shifts between low and high effective mositure under Oxygen isotopes variable dry to wet climatic regime, possibly accompanied by cooler conditions

Saline - alkaline lake

Shallow eutropic lake with methane formation

Stable catchment with limited inwash
Ostracods, diatoms

Elemental geochemistry and magnetic susceptibility

Oxygen isotopes

Ostracods, diatoms

Carbon isotopes

Elemental geochemistry and magnetic susceptibility

Oxygen isotopes

Ostracods, diatoms

Stratography (presence of desiccation surface)

Oxygen isotopes

Stratography (presence of desiccation surface)

Ostracods, diatoms

Diatoms, carbon isotopes

Elemental geochemistry and magnetic susceptibility

Ostracods, diatoms

Diatoms, carbon isotopes

Elemental geochemistry and magnetic susceptibility 


\section{Supporting online information}

1172 Table S1. Water Chemistry for La Piscina de Yuriria. Date from Davies (1995) and various

1173 unpublished sources.

Table S1. Water Chemistry for La Piscina de Yuriria. Date from Davies (1995) and various unpublished sources.

\begin{tabular}{|c|c|c|c|c|c|c|c|c|c|c|c|c|c|c|c|}
\hline Year & $\begin{array}{l}\text { Water depth } \\
\quad(\mathrm{m})\end{array}$ & Type & $\mathrm{pH}$ & $\begin{array}{c}E C^{n} \\
(\mu \mathrm{Scm}-1)\end{array}$ & $\begin{array}{c}\text { Alkalinity (Total) } \\
\left(\mathrm{meqL}^{-1}\right)\end{array}$ & $\begin{array}{c}\mathrm{Cl} \\
\left(\mathrm{meqL}^{-1}\right)\end{array}$ & $\begin{array}{c}\mathrm{SO}_{4} \\
\left(\mathrm{meqL}^{-1}\right)\end{array}$ & $\begin{array}{c}\mathrm{K} \\
\left(\mathrm{meqL} \mathrm{L}^{-1}\right)\end{array}$ & $\begin{array}{c}\mathrm{Na} \\
\left(\mathrm{meqL}^{-1}\right)\end{array}$ & $\begin{array}{c}\mathrm{Ca} \\
\left(\mathrm{meqL}^{-1}\right)\end{array}$ & $\begin{array}{c}\mathrm{Mg} \\
\left(\mathrm{meqL}^{-1}\right)\end{array}$ & $\begin{array}{c}\mathrm{TP} \\
\left(\mu \mathrm{gL}^{-1}\right)\end{array}$ & $\begin{array}{c}\delta^{13} \mathrm{C}_{\text {DIC }} \\
\% \text { VPDB }\end{array}$ & $\begin{array}{c}\delta^{18} \mathrm{O} \\
\% \text { VSMOW } \%\end{array}$ & $\begin{array}{c}\text { SD } \\
\text { 6o VSMOW }\end{array}$ \\
\hline 1982 (April) & 2 (surface) & Lake & 11.0 & 26000 & 300.0 & 174.3 & 29.3 & 30.7 & 478.5 & 0.0 & 0.0 & $\mathrm{ND}^{\#}$ & ND & ND & ND \\
\hline 1982 (April) & 2 (at depth) & Lake & NA & 23000 & 326.0 & 141.5 & 30.2 & 24.8 & 478.5 & 0.0 & 0.0 & ND & ND & ND & ND \\
\hline 1982 (April) & 0.2 (margin) & Lake & 11.0 & 29000 & 294.0 & 116.3 & 29.5 & 32.1 & 413.3 & 0.0 & 0.0 & ND & ND & ND & ND \\
\hline 1982 (April) & & Spring & 7.5 & 500 & 6.2 & 0.4 & 1.4 & 0.6 & 3.7 & 1.0 & 1.3 & ND & ND & ND & ND \\
\hline 1982 (April) & & Spring & 7.0 & 1100 & 5.0 & 1.1 & 3.6 & 1.0 & 9.6 & 1.1 & 1.6 & ND & ND & ND & ND \\
\hline 1982 (May) & 0.2 (margin) & Lake & 9.6 & 27500 & 333.0 & 203.0 & 33.5 & 32.1 & 543.7 & 0.0 & 0.0 & ND & ND & ND & ND \\
\hline 1982 (May) & & Spring & 7.7 & 700 & 8.0 & 4.2 & 0.3 & 0.6 & 8.9 & 0.9 & 1.6 & ND & ND & ND & ND \\
\hline 1992 (August) & 0.2 & Lake & 10.5 & 15620 & 248.2 & 117.4 & 50.0 & 22.8 & 298.5 & 0.3 & 0.1 & ND & -0.2 & 0.7 & -25 \\
\hline 1992 (August) & & well & 6.8 & 315 & 3.7 & 0.4 & 9.6 & 0.9 & 5.7 & 4.4 & 3.9 & ND & -10.4 & -9.2 & -69 \\
\hline 1992 (August) & & spring & 8.0 & 452 & 7.7 & 0.4 & 7.5 & 2.0 & 8.4 & 3.3 & 3.7 & ND & -11.6 & -9.1 & -69 \\
\hline 1997 (March) & shore & Lake & 10.2 & 8130 & 68.3 & 27.5 & 9.2 & 7.0 & 95.8 & 5.9 & 1.9 & ND & ND & ND & ND \\
\hline 2003 (March) & 0.2 (margin) & Lake & 9.5 & 1907 & 20.8 & 6.2 & 0.4 & 1.7 & 26.3 & 2.9 & 2.4 & 562.0 & ND & ND & ND \\
\hline 2004 (July) & 0.2 (margin) & Lake & 9.6 & 2910 & 16.4 & 16.7 & 0.8 & 1.5 & $163.4^{*}$ & 2.6 & 0.0 & 744.5 & ND & ND & ND \\
\hline 2003 (March) & & Groundwater & 8.0 & 1076 & ND & ND & ND & ND & ND & ND & ND & ND & ND & ND & ND \\
\hline
\end{tabular}

${ }^{\wedge}$ Electrical conductivity

\#ND = not determined

1174 * possible contamination

1175

1176

1177

1178

1179

1180

1181

1182

1183

1184

1185

1186

1187

1188

1189 
1190 Table S2. Correlation matrices $\left(R^{2}\right.$ values) for correlation amongst selected geochemical

1191 variables from (a) YC1 (b) YC2, whole core (c) YC2 post 5000 aBP. In each table the null

1192 hypothesis $\left(\mathrm{H}_{\mathrm{o}}\right)$ is that there is no statistically-significant relationship between the two

1193 variables

Table S2. Correlation amongst selected geochemical variables

(a) Core YC1

\begin{tabular}{|c|c|c|c|c|c|}
\hline & & K & $\mathrm{Fe}$ & $\mathbf{M n}$ & Al \\
\hline $\mathrm{K}$ & $\begin{array}{l}\mathbf{R}^{2} \\
p \text {-value } \\
\mathrm{HO}(5 \%)\end{array}$ & 1. & & & \\
\hline $\mathrm{Fe}$ & $\begin{array}{l}\mathbf{R}^{\mathbf{2}} \\
p \text {-value } \\
\text { HO (5\%) }\end{array}$ & $\begin{array}{c}\mathbf{0 . 6 5} \\
1.68 \mathrm{E}-16 \\
\text { rejected }\end{array}$ & 1. & & \\
\hline$M n$ & $\begin{array}{l}\mathbf{R}^{2} \\
p \text {-value } \\
\text { HO (5\%) }\end{array}$ & $\begin{array}{c}\mathbf{0 . 6 8} \\
8.35 \mathrm{E}-18 \\
\text { rejected }\end{array}$ & $\begin{array}{c}\mathbf{0 . 7 7} \\
0.00 \mathrm{E}+00 \\
\text { rejected }\end{array}$ & 1. & \\
\hline Al & $\begin{array}{l}\mathbf{R}^{2} \\
p \text {-value } \\
\text { HO (5\%) }\end{array}$ & $\begin{array}{c}\mathbf{0 . 5 2} \\
4.76 \mathrm{E}-12 \\
\text { rejected }\end{array}$ & $\begin{array}{c}\mathbf{0 . 9 0 1} \\
0.00 \mathrm{E}+00 \\
\text { rejected }\end{array}$ & $\begin{array}{c}\mathbf{0 . 6 7} \\
2.46 \mathrm{E}-17 \\
\text { rejected }\end{array}$ & 1. \\
\hline
\end{tabular}

(b) Core YC2 - all

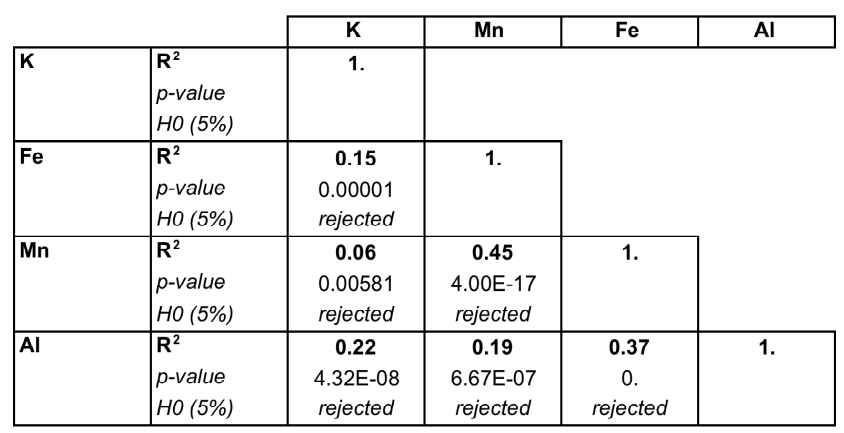

(b) Core YC2 - post 5000 aBP

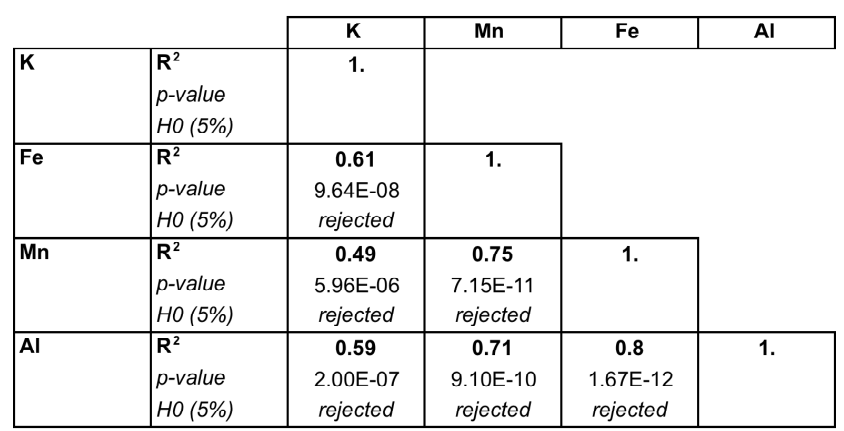

1194 